\title{
Role of Spices in Offering Natural Immunity to Fight Various Diseases
}

\author{
T. Sudhakar Johnson ${ }^{1}$, D. B. Anantha Narayana ${ }^{2, *}$
}

\section{T. Sudhakar Johnson ${ }^{1}$, D. B. Anantha Narayana ${ }^{2, *}$}

'Technical and Regulatory, Viridis Biopharma Pvt Ltd, Govandi, Mumbai-400 043, INDIA.

${ }^{2}$ Chief Scientific Officer, Ayurvidye Trust, and Chairman, Scientific Panel, Nutraceuticals, Food Safety Standards Authority of India (FSSAI), Ministry of Health and Family Welfare, INDIA.

\section{Correspondence \\ Dr DBA Narayana}

1 ' $F$ ' Main Road, 2nd Stage, Giri Nagar, Bangalore-560 085, INDIA.

Phone no: +91-080-26420775

E-mail: drandba50@gmail.com

History

- Submission Date: 14-11-2020;

- Review completed: 03-01-2021.

- Accepted Date: 11-01-2021.

DOI : 10.5530/pj.2021.13.76

Article Available online

http://www.phcogj.com/v13/i2

Copyright

(C) 2021 Phcogj.Com. This is an openaccess article distributed under the terms of the Creative Commons Attribution 4.0 International license.

\begin{abstract}
Adequate nutrition intake is one of main factors to strengthen immunity. Traditional and cultural practices of food consumption involve use of several spices in limited quantities as part of food. Spices have offered versatile biological effects due to presence of valuable biochemicals. The aim of the present paper is to review published scientific evidence on potential role of spices in offering innate and adaptive immunity to human body. It has been demonstrated that, turmeric, one of the widely used spices, acts as an anti-viral agent through inhibition of viral entry into cells, suppression of viral replication and modulation of cytokines. A field study revealed that nations with higher consumption of spices have shown lesser COVID-19 cases and higher recovery rates. Further, spices also have shown to possess antioxidant activity superior or equivalent to ascorbic acid and are known to regulate inflammation processes. Evidence generated from the published literature is compelling to arrive at a conclusion that consumption of spices might improve immunity there by offering protection against various diseases including COVID-19. It is also noted that there are lesser number of human clinical trials in this area which warrants immediate attention to provide scientific evidence to immunity offered by spices.
\end{abstract}

Key words: COVID-19, Spices, Immunity, Diet, Nutrition.

\section{INTRODUCTION}

Traditional foods, traditional medicines and Ayurveda (Indian system of medicine) have long history of safe use to maintain health. It is a holistic approach which means that they target root cause of disease but not symptoms. They offer preventive care strengthening body's immunity to fight disease. Underlying principle of helping to maintain health is by boosting body's natural defense system. Consumption of spices and condiments in small quantities as a part of diet on a regular basis has been proven to strengthen body's immunity. A detailed account on various traditional foods and the global regulatory guidelines were published.

During early stages of COVID-19 (coronavirus disease-19) pandemic, Ministry of Ayush, Government of India issued guidelines and prescribed usage of spices in order to develop body's natural defense system. The guidelines were result of a consensus approach of taking documentary evidence from the prescribed texts in addition to suggestions from a team of experienced clinicians. The consensus approach recommended consumption of spices to build body's immune system. Further, it also recommended application of oils to prevent entry of virus or bacteria into the nose (Table 1). An article recommending diet during the COVID-19 pandemic has been published recently. ${ }^{2}$ Spices, especially turmeric and its alkaloids were found to act as anti-viral agents to inhibit Influenza Type-A, Hepatitis A, Zika, HIV, H5N1, hepatitis B, Hepatitis C, chikungunya anddengue. ${ }^{3}$
Spices include volatile oils/essential oils like cardamom oil; oleoresins like turmeric oil; alkaloids like capsaicin, piperine; saponins like trigonellenine; colorants like crocin, carotene and odd flavors like asafetida (Table 2).In parts of Asia, South-east Asia and in particular India, due to diverse cultural background different spices are used in different seasons in different foods and different types of cooking. For e.g. one of the widely used spices, turmeric offers plethora of benefits so much so that it is now used to treat cancer, chemoprevention, protecting elderly from Alzheimer's disease.

We believe that the consumption of spices everyday as part of diet (mixed in hot water, ghee, oil, milk or direct) offers significant protection by providing immunity. The list of commonly available spices along with the major constituents is available (Table 2).Due to COVID-19 pandemic and subsequent lockdown, Government promoted and partially funded researchers on generation of human safety and efficacy data on a number of products containing spice ingredients and spices. Having found evidence on potential role of spices in offering immunity to fight various diseases, we aimed at reviewing published scientific literature. Few publications have directly linked consumption of turmeric to control of COVID-19. ${ }^{4}$ Yet another report correlated nations with higher consumption of per capita had lower number of COVID-19 cases per million. ${ }^{5}$ We have also listed a number of human clinical trials that are being conducted on COVID-19 front line warriors using spices as ingredients. Spices were found to possess activities to regulate inflammation processes and inhibit abnormal cytokine release. Furthermore,

Cite this article: Johnson TS, Narayana DBA. Role of Spices in Offering Natural Immunity to Fight Various Diseases. Pharmacog J. 2021;13(2): 600-13. 
Table 1: Consensus approach recommended for consumption of spices to boost immunity with special reference to respiratory health by the Ministry of AYUSH, Government of India during COVID-19 pandemic based on Indian system of medicine and traditional foods (AYUSH 2020).

\begin{tabular}{cl}
\hline SI No & Spice/ ingredients \\
\hline 1 & $\begin{array}{l}\text { Spices like turmeric, cumin, coriander and } \\
\text { garlic to be used in cooking }\end{array}$ \\
2 & $\begin{array}{l}\text { Herbal decoction made from basil leaves, cinnamon bark, black pepper, dry ginger and raisins mixed with jiggery and fresh lemon juice to be consumed as } \\
\text { warm/hot tea twice a day. }\end{array}$ \\
3 & Half tea spoon turmeric powder in hot milk called golden milk \\
4 & Nasal application of sesame oil or coconut oil or ghee \\
6 & Cteam inhalation of fresh mint leaves or caraway seeds once in a day to treat dry cough and sore throat
\end{tabular}

\section{Table 2: List of important spices and their major constituents.}

\begin{tabular}{ccl}
\hline SI No & Name of the spice & Major constituents \\
\hline 1 & Asafoetida & AsacoumarinB,farnesferol A-C, \\
2 & Capsicum & Capsaicinoids, flavonoids, capsanthin and natural colors \\
3 & Cardamom & 1,8 -cineole, $\alpha$-terpinyl acetate, $\alpha$-terpinyl acetate, $1-8$ cineole, limonene and linalool \\
4 & Cinnamon & Cinnamaldehyde, eugenol, O-methoxycinnamaldehyde and monoterpenoids \\
5 & Coriander & D-linalool, neryl acetate, $\gamma$-terpinene, camphor, $\alpha$-pinene and geranyl acetate \\
6 & Turmeric & Turmerone, ar-turmerone and zingiberene, curcuminoids \\
7 & Cuminum & Flavonoid glycosides, tannin. Essential oil contains cuminic aldehyde, $\beta$-pinene, triterpene, p-cymene, $\beta$-farnesene \\
8 & Fenugreek & fFavonoids, trigonelline, choline, gentianine and saponins. Essential oil contains $\beta$-pinene, camphor, $\beta$-caryophyllene and \\
9 & Ginger & Zingiberene, ar-curcumene, gingerols, shogaols and zingerone. \\
10 & Mustard & Allyl isothiocyanate \\
11 & Black pepper & $\alpha$-pinene, $\beta$-pinene, $\beta$-caryophyllene, limonene, piperine, brachymide B. Quercetin, isoquercetin, isorhamnetin, kaempferol \\
\hline
\end{tabular}

spices have shown antioxidant activity superior or equivalent to ascorbic acid. Based on the outcome we have arrived at reasonable conclusion that consumption of spices can provide innate and adaptive immunity in fighting various diseases including COVID-19.

We have searched Google, Google Scholar, PubMed, SciELO, Cochrane, Science Direct, Clinical Trial Registry, India (CTRI). Our search was limited to finding role of spices in offering anti-inflammatory activity, immunomodulation and anti-oxidant protection.

It is mandatory that all human clinical studies including herbal medicines, traditional medicines, pharmaceuticals and biopharmaceuticals have to register with CTRI, Indian Council of Medical Research, Government of India. For the purpose of the current study we have accessed CTRI website and collected various clinical studies registered for testing on common asymptomatic persons, front line workers either as protective, prophylactic or as add-on. We have shortlisted those clinical studies that were having products with one or more spices as ingredient. Table 3 summarizes clinical trials registered to undertake human studies containing one or spices as ingredients. Traditional remedies and Ayurvedic remedies are licensed under Drugs and Cosmetic Act(DCA-1940) and Rules, 1940 in India which are revised from time to time under the supervision of apex body.

\section{COVID-19 and immunity}

Immunity is defined as the body's ability to detect and resist a number of invading pathogens, infections enabling the body to prevent or resist disease, inhibit organ or tissue damage. Immunomodulators are biological or chemical molecules or substances that can stimulate, suppress or modulate either innate or adaptive immunity or both by offering immunity against pathogens.

World is now facing uncontrolled pandemic with the outbreak of new Corona virus (SARS-CoV-2) infection infecting millions of people all over the world. ${ }^{6}$ Clinicians categorized COVID-19 patients into three stages, viz. stage-I, an asymptomatic incubation period; stage-II, nonsevere symptomatic period with the presence of virus and stage-III, severe respiratory-symptomatic stage with high viral load. ${ }^{6}$ Defense against viral infection is offered by body's innate and adaptive immunity. Effective anti-viral responses of host's innate and adaptive immunity including production of proinflammatory cytokines, the activation of T-cells, CD4+ and CD8+ and T-cells are essential for controlling viral replication and inflammation. ${ }^{7}$ In COVID-19 patients, count of neutrophils and leukocytes increase whereas the total count of lymphocytes CD4+ T cells, CD8+ T cells, regulatory $\mathrm{T}$ cells, memory $\mathrm{T}$ cells, natural killer cells and $\mathrm{B}$ cells decrease. The unusual pro-inflammatory cytokine production is observed in patients with severe symptoms leading to acute respiratory distress syndrome (ARDS). Currently there are no treatments available but existing antiviral therapies and other immunomodulatory and immunosuppressive treatments are used on case to case basis. Immunomodulatory therapies such as(interleukin)IL-6 antagonists, granulocyte colony stimulating factor (GM-CSF) inhibitors, IL-1 antagonists, IL-17 antagonists and anti-tumor necrosis factor (TNF) agents might be used for abnormal cytokine production and limit inflammational tissue damage. ${ }^{7}$ We have provided here fundamental information on immunity and existing therapies to treat COVID-19. However, reviewing COVID-19 disease in detail is out of the scope of this article. Readers are requested to consult relevant topics for advanced knowledge on the same.

\section{Spices and their role in offering immunity- Review of literature}

Capsicum (Capsicum annuum L.): Capsicum is one of the important spices used widely in diet. It improves the flavor and taste by adding pungency to the preparations. The pungency is due to presence of an alkaloid called capsaicin in chili pepper fruit. Parts of Capsicum used as spice are; fruit powder, whole fresh fruit and dry fruit and in isolated form phenolics, flavonoids, capsaicinoids, natural colors, oleoresin and essential oils are used. Capsicum not only adds taste and improves color but also masks unwanted smell characteristic of meat and fish products. Like asafoetida, capsicum has carminative property. It also aids in improving digestion and bio-availability in the gut. Components of red 
Table 3: List of Clinical trials registered with CTRI, ICMR as on $15^{\text {th }}$ July 2020. Clinical trials were tabulated based on Spices as one of the main ingredient or Ayurvedic formulations that are under human clinical trials for immunity and treatment for COVI-19.

\begin{tabular}{|c|c|c|c|c|}
\hline $\begin{array}{c}\text { CTRI Number } \\
\text { (Clinical Trial Number) }\end{array}$ & Title & Health condition & Intervention Name/ Product & Location \\
\hline CTRI/2020/06/025801 & $\begin{array}{l}\text { Role of Herbal Imunomodulators in } \\
\text { mild COVID-19 confirmed cases }\end{array}$ & $\begin{array}{l}\text { Corona virus as the } \\
\text { cause of diseases } \\
\text { classified elsewhere }\end{array}$ & $\begin{array}{c}\text { Tab. Bresol } \\
\text { (contains Curcuma longa, Cinnamomum } \\
\text { zeylanicum, Ocimumsanctum,Elettaria } \\
\text { cardamomum Cinnamomum tamala and } \\
\text { few other medicinal herbs) }\end{array}$ & $\begin{array}{l}\text { Bangalore Medical college and } \\
\text { research institute, Karnataka, } \\
\text { India }\end{array}$ \\
\hline CTRI/2020/05/025273 & $\begin{array}{l}\text { Impact of effect of Ayurvedic treatment } \\
\text { on novel Corona virus disease }\end{array}$ & $\begin{array}{l}\text { Respiratory failure, } \\
\text { unspecified }\end{array}$ & Ayurvedic treatment & $\begin{array}{l}\text { National Institute of } \\
\text { Medical } \\
\text { Sciences, Rajasthan, India }\end{array}$ \\
\hline CTRI/2020/05/025430 & $\begin{array}{l}\text { Effect of ayurveda immunomodulator } \\
\text { Drugs on health of corona warriors }\end{array}$ & $\begin{array}{l}\text { Healthy personnel's } \\
\text { engaged in care of } \\
\text { covid-19 infected/ } \\
\text { suspected persons }\end{array}$ & $\begin{array}{l}\text { Decoction (contains Piper longum fruit } \\
\text { and Tinospora cordifolia stem) }\end{array}$ & $\begin{array}{l}\text { Dr S R Rajasthan Ayurved } \\
\text { University, Rajasthan, India }\end{array}$ \\
\hline CTRI/2020/05/024981 & $\begin{array}{l}\text { Clinical study on Dabur Chyawanprash } \\
\text { as a preventive remedy in pandemic of } \\
\text { COVID- } 19 .\end{array}$ & $\begin{array}{l}\text { Immunity in } \\
\text { Healthy } \\
\text { Individuals }\end{array}$ & $\begin{array}{l}\text { Dabur } \\
\text { Chyawanprash (traditional product with } \\
\text { winter cherry and ten other spices as } \\
\text { ingredients) }\end{array}$ & Multiple locations \\
\hline CTRI/2020/06/025592 & $\begin{array}{c}\text { Use of Herbal Medicine } \\
\text { likeTulasi,Amruth(Giloy), } \\
\text { Turmeric,Ashwagandha as add on } \\
\text { treatment in COVID-19 Patients }\end{array}$ & $\begin{array}{l}\text { Coronavirus as the } \\
\text { cause of diseases } \\
\text { classified elsewhere }\end{array}$ & $\begin{array}{l}\text { Immunity Kit (contains turmeric and } \\
\text { other medicinal herbs) }\end{array}$ & $\begin{array}{c}\text { Bangalore Medical college and } \\
\text { research institute, Karnataka, } \\
\text { India }\end{array}$ \\
\hline CTRI/2020/05/025434 & $\begin{array}{l}\text { A clinical trial to evaluate the Medicinal } \\
\text { effects of ZingiVir-H as Anti-Viral } \\
\text { therapy in COVID-19 patients }\end{array}$ & $\begin{array}{l}\text { Coronavirus as the } \\
\text { cause of diseases } \\
\text { classified elsewhere }\end{array}$ & Zingivir-H (Ginger is ingredient) & Multiple locations \\
\hline CTRI/2020/05/025317 & $\begin{array}{l}\text { Survey of mouth-dissolving turmeric } \\
\text { lozenges in healthcare workers }\end{array}$ & $\begin{array}{l}\text { Healthcare team } \\
\text { serving duties at } \\
\text { COVID-19 wards }\end{array}$ & $\begin{array}{l}\text { Turmgel mouth dissolving lozenge } 100 \\
\text { mg (Turmeric as ingredient) }\end{array}$ & $\begin{array}{l}\text { KJ Somaiya Medical College } \\
\text { and Hospital, Maharashtr, } \\
\text { India }\end{array}$ \\
\hline CTRI/2020/05/025156 & $\begin{array}{l}\text { Effect of Ayurveda intervention } \\
\text { AYUSH-64 add-on therapy for patients } \\
\text { with COVID-19 infection (Stage I) }\end{array}$ & $\begin{array}{l}\text { Coronavirus as the } \\
\text { cause of diseases } \\
\text { classified elsewhere }\end{array}$ & $\begin{array}{l}\text { Group I: Ayurveda intervention } \\
\text { AYUSH-64 as add-on to standard } \\
\text { treatment }\end{array}$ & $\begin{array}{l}\text { Government Medical College, } \\
\text { Nagpur, Maharashtra, India }\end{array}$ \\
\hline CTRI/2020/07/026371 & $\begin{array}{l}\text { KabasuraKudineer, Shakti drops } \\
\text { andTurmeric plus in the management of } \\
\text { COVID-19 }\end{array}$ & $\begin{array}{l}\text { Coronavirus as } \\
\text { thecause of diseases } \\
\text { classified elsewhere }\end{array}$ & $\begin{array}{c}\text { 1.Shakti Drops (Nasal administration) } \\
\text { 2.Turmeric } \\
\text { plus tablets (Turmeric as an ingredient) }\end{array}$ & $\begin{array}{c}\text { Mazumder Shaw Medical } \\
\text { Centre, Narayana } \\
\text { Hrudayalaya, Bangalore, } \\
\text { Karnataka, India }\end{array}$ \\
\hline
\end{tabular}

Abbreviations: CTRI, The Clinical Trials Registry- India; ICMR, Indian Council of Medical Research. List is representative and not exhaustive.

pepper total phenolics, capsanthin, beta-carotene have been shown to prevent oxidation of cholesterol during heating. ${ }^{8}$ Several reports on role of capsicum extracts and alkaloids on immunomodulation have been published. Takono et al. ${ }^{9}$ reported that capsicum extract and capsaicin suppressed IL-2, interferon- $\gamma$, IL- 4 and IL- 5 production and reduction in CD3 cells and increase in CD-19 cells. It was found that capsicum extract modulate T-cell immune response via vanilloid receptor subfamily of TRP ion channels (TRPV1)-dependent and independent pathway. ${ }^{9,10}$ Capsaicin promoted (Dendritic cells) DC activation and it counteracted the immune suppression. ${ }^{11}$ In a study conducted on Jurkat T-cells (human leukemic T-cell line), capsaicin suppressed both T-cell receptor dependent and T-cell receptor independent production of IL$2 .{ }^{12}$ Anti-inflammatory activities of pepper are also well documented. Bell pepper leaf extracts inhibited inflammatory cytokine production, inhibited cell proliferation without producing cytotoxicity and suppressed the expression of inflammatory proteins. ${ }^{13}$ Similarly red pepper fruit showed anti-inflammatory activity via nitric oxide (NO) scavenging activity. ${ }^{14}$ Likewise, green pepper showed lipooxygenase (LOX)inhibition followed by yellow and red pepper. ${ }^{15}$ Sanchez et al. ${ }^{16}$ reported that capsaicin inhibited early and late events in T-cell activation.

Several in-vivo studies were carried out to support immunomodulatory activity of capsicum extracts and its metabolites. On Wistar rats, ${ }^{17}$ showed marked inhibition of natural killer (NK) cell and antibody dependent cytotoxic function. Santonietal. ${ }^{18}$ also demonstrated strong correlation between inhibition of cell proliferation and decreased numbers of $\mathrm{CD} 5+$ and CD4. On Wistar rats, capsicum extracts suppressed IL-2, interferon- $\gamma$, IL-4 or IL-5 production. Beltran et al. ${ }^{10}$ showed capsaicin-elicited immunity is $\mathrm{T}$ cell-mediated process. Jang et al. ${ }^{19}$ demonstrated that capsicum extracts significantly reduced ovalbumin-induced allergic airway inflammation. Hernandez-Ortega et $a l .{ }^{20}$ studied anti-inflammatory activity in mice. It was found that Guajillo pepper carotenoid extract significantly inhibited oedema formation and progress. Potential of immunomodulatory activity was studied in neonatal and adult rats by Nilsson andAhlstedt. ${ }^{21}$ They found significant decrease in lymphocyte proliferative response to suboptimal concentrations of concanavalin $\mathrm{A}(\mathrm{Con} \mathrm{A})$. In studies conducted on $\mathrm{BALB} / \mathrm{c}$ mice, capsaicin was found to increase serum immunoglobulin concentrations (IgG and IgM).22

Cardamom (Elettaria cardamomum L.): Cardamom flavor is one of the pleasant among the spices. It has aromatic odor and slightly pungent taste. Important parts of economic use are cardamom essential oil, metabolites and oleoresins. As a spice it is used directly or powdered. Major constituents of volatile oil are 1,8-cineole and $\alpha$-terpinyl acetate. Seed oil has $\alpha$-terpinyl acetate, 1-8 cineole, limonene and linalool. Like asafoetida and capsicum, cardamom is used as carminative. But in Ayurveda cardamom is offered as a remedy for digestive problems. In addition, cardamom has many other pharmacological activities. It is used as an antioxidant, anti-inflammatory and immunomodulatory agent. We will review some of these activities below. Aqueous extract of cardamom was found to have immunomodulatory role. ${ }^{23}$ Regular consumption of tea fortified with cardamom was shown to enhance 
NK cell activity which is part of early innate immune response to infections. ${ }^{24}$ Aqueous extracts of cardamom also provided protective effects on colon carcinogenesis induced in vitro. ${ }^{25}$ Aqueous extracts were shown to enhance the level of detoxifying enzyme with decrease in lipid peroxidation levels. ${ }^{26}$

The essential oil had significant antioxidant activity. ${ }^{27}$ Methanol extracts have protective ability against proxy nitrite mediated biomolecular damage. ${ }^{28}$ Spice mixture containing cardamom reduced the levels of peroxidation markers in tissues and improved antioxidant status in male Wistar rats. ${ }^{29}$ Cardamom showed 2,2-diphenyl-l-picrylhydrazyl(DPPH) radical scavenging activity. ${ }^{30}$ Several in vitro based experiments were conducted to study various pharmacological activities of cardamom. Nair et al. ${ }^{31}$ have concluded that cardamom has moderate levels of natural antioxidant properties due to presence of phenolics such as quercetin, kaempferol. Essential oils of cardamom also act as an antioxidant and helps in scavenging free radicals. ${ }^{32,33}$ In vivo studies using Sprague Dawley rats, Raksamiharja et al..$^{34}$ showed that distillate of cardamom increases the amount of lymphocyte, white blood, CD4+ and CD8+ cells and has potential to develop into immunostimulating agent. In another study Al-Zuhair et al. ${ }^{35}$ showed oil extract of cardamom reduced inflammation in carrageenan induced rat paw oedema.

Cinnamon (Cinnamomum zeylanicum Garcin ex Blume): Cinnamon as a spice is known since Biblical times and is one of the oldest known spices. Similar to cardamom, cinnamon is sweet spice with pleasant aroma and taste. Cinnamon bark, essential oil and oleoresins have proven medicinal uses since olden times. Important constituents of cinnamon are cinnamaldehyde, eugenol, O-methoxycinnamaldehyde and monoterpenoids. It is traditionally used to treat flatulence, loss of appetite and as a carminative. However, cinnamon has anti-oxidant, anti-inflammatory and immunomodulatory roles in addition to many other benefits. ${ }^{36}$ The methanolic extract has an excellent NOscavenging ability through the mechanism of inhibition of iNOS expression. ${ }^{37}$ Cinnamol polyphenol extract was found to reduce OGD induced cell swelling. ${ }^{38}$ Treatment with cinnamon extract inhibited maturation of MHC II (+)(Major Histocompatibility Complex) APCs or CD11C $(+)$ dendritic cells by suppressing expression of cylcooxygenase-2 (COX-2) and MHC II. Cinnamon extract also induced dendritic cells that produce low levels of proinflammatory cytokines IL- $1 \beta$, IL- 6 , IL-12, IFN- $\gamma$ and TNF- $\alpha$ while expressing high levels of immunoregulatory cytokines. These results suggested the potential of cinnamon extracts as a source of an anti-inflammatory cytokines. ${ }^{23}$ The essential oil of cinnamon was shown to have antioxidant activity using in vitro models. ${ }^{39} \mathrm{~A}$ concentrated water extract of cinnamon contained the maximum amount of phenolics and showed antioxidant activities. ${ }^{40}$ Kim et al. ${ }^{41}$ reported cinnamaldehyde to possess anti-inflammatory activities and a role in regulation of age-related metabolic pathways. Cinnamaldehyde inhibited the activation of NF- $\kappa B$ via three signal transduction pathways, NF- $\kappa \mathrm{B}$-inducing kinase/IкB kinase (NIK/IKK), ERK and p38 MAPK.

Several in vitro studies have been conducted to identify and establish role of cinnamon and its metabolites in offering immunomodulation. C. zeylanicum aqueous extract significantly induced thymic cells lymphoproliferation. Further, spice aqueous extracts significantly reduce up to $100 \%$ nitric oxide production by LPS-stimulated macrophages. ${ }^{42}$ Ethanolic extract suppressed P.acnes stimulated NF$\kappa \mathrm{B}$ mediated TNF- $\alpha$, IL-1B and IL-8 production. ${ }^{43}$ Water extract also inhibited anti-CD3 Ab-stimulated IFN- $\gamma$ and IL- 4 at the mRNA and secreted protein level. ${ }^{44}$ Extract has inhibitory effect on LPS-induced activity of NF- $\kappa B$.

Main constituents of cinnamon, eugenol and cinnamaldehyde have promoted anti-inflammatory activity. ${ }^{45}$ Gruenwaldet al. ${ }^{46}$ has shown that above compounds of cinnamon inhibited COX-2 enzymes. 2-hydroxycinnamaldehyde inhibited LP stimulated NO production and NF- $\kappa B$ activation via redox-related NF- $\kappa \mathrm{B} / \mathrm{IKK}$ and mitogen activated MAPK pathway through reduction of oxidative stress. ${ }^{41}$

In-vivo studies related to role of cinnamon have been studied. In immune-compromised mice, bark extracts of cinnamon have improved humoral, cellular and innate response of immune system. ${ }^{47}$ Low dose of cinnamon produced an increase in serum immunoglobulin's and high dose decreased Pasteurella muttocida induced mortality by $17 \%$; increased the phagocytic index in carbon clearance test, increased neutrophil adhesion, increased serum immunoglobulin levels and antibody titer values. ${ }^{48}$ There is one clinical trial conducted on human subjects in double-blind, placebo controlled design on 34 female breast cancer patients to study cinnamon's role as chemo-preventive agent. Cinnamon bark extract showed significant protection from chemotherapy -induced severe weight loss and alopecia. ${ }^{49}$

Coriander (Coriandrum sativum L.): Coriander is also an oldest known spice in the history. Coriander is a popular flavor used to flavor almost every cooking due to its characteristic aroma. Coriander fresh leaves are most widely used plant part. However, dried seeds are also used in special spice mixtures. In addition, coriander's alkaloids, essential oils and oleoresins have important pharmacological importance. The major constituents of oil are D-linalool, neryl acetate, $\gamma$-terpinene, camphor, $\alpha$-pinene and geranyl acetate. ${ }^{23}$ Major constituents of seed and fresh leaves are tocopherols, carotenoids, phenolics, flavanols and anthocyanins. Coriander is carminative, stomachic, spasmolytic and antibacterial. Essential oil is having excellent anti-bacterial, antifungal and anti-microbial activity. Furthermore, coriander has proven antioxidant activity. It is an effective antioxidant showing DPPH radical scavenging activity, lipoxygenase inhibition, phospholipid peroxidation inhibition, hydroxyl radical scavenging activity, SOD activity and antilipid peroxidation. Ethanolic, methanolic, chloroform, ethylacetate and water extracts were found to have high total phenolic content. ${ }^{50}$ Sreelatha et al. ${ }^{51}$ reported protection of liver from oxidative stress induced by $\mathrm{CCl}_{4}$. The aqueous extract has superior antioxidant activity equivalent to ascorbic acid..$^{52}$ Extracts also have anti-inflammatory activity which inhibits proinflammatory mediator expression by suppressing NF- $\kappa \mathrm{B}$ activation and MAPK signal transduction pathway in LPS induced macrophages.$^{53}$ Hot water extract has high antioxidant activity owing to presence of phenolics and flavonoids. ${ }^{54}$ The ethanolic extract has hepatoprotective activity which might be due to antioxidant potential of phenolics. ${ }^{55}$

Few in vitro studies have been conducted on coriander extracts. Aqueous and methanolic extract caused significant L5178Y- R lymphoma cell toxicity showing anti-tumor activity. ${ }^{42}$ The aqueous crude extracts stimulated the proliferation of human peripheral blood mononuclear cells (PBMC) and the secretion of IFN- $\gamma \cdot{ }^{56,57}$ Methanolic extracts exhibited remarkable DPPH radical scavenging activity due to the presence of rich antioxidants. ${ }^{58}$ Methanolic extracts showed better antioxidant activity than ethanolic extract and the DPPH radical scavenging ability of methanolic extract was higher than that of BHT. ${ }^{59,60} \mathrm{Al}$ Mofleh et al. ${ }^{61}$ compared the activities between leaf and seed extracts. Upon comparison it was found that leaf ethyl acetate extract showed most potent DPPH radical scavenging activity. Singletary 2016 showed that coriander extract reduced hepatic damage, liver oxidative damage and brain oxidative stress and at the same time activity of antioxidant enzymes increased thereby showing correlation between protection against oxidative damage and antioxidant enzymes. In vivo studies conducted on rats showed that the extract inhibited $40.81 \%$ oedema after third hour of treatment at $200 \mathrm{mg} / \mathrm{g}$ dose. ${ }^{62}$

A study on role of coriander on human (ultraviolet erythrema test) was carried out by Reuter et al. ${ }^{63}$ The lipolotion with $0.5 \%$ coriander 
essential oil reduced significantly the UV-induced erythrema. It was also found that extract was well tolerated.

Turmeric (Curcuma longa L.):Turmeric is one of the most commonly and widely used spices. Rhizome is plant part of importance. Dried rhizome is used after powdering in several food preparations. Mixed in hot milk if consumed, the golden milk offers immunity (Table 1). Turmeric powder is applied on face as paste to control acne formation. In some traditional homes, turmeric and neem leaves are mixed and boiled. This mixture is given as bath to convalescing patients recovering from skin diseases, bacterial and viral diseases. Therefore, turmeric is a household remedy. Recently a Chinese group investigated the antiviral properties of curcumin against Transmissible gastroenteritis virus (TGEV). It was demonstrated that curcumin strongly inhibited TGEV proliferation and viral protein expression in a dose-dependent manner. They also observed that curcumin exhibited direct virucidal abilities in a dose-, temperature- and time-dependent manner. Mode of action was that curcumin acted in early phase of TGEV replication. The group also suggested that curcumin might be a candidate drug for effective control of TGEV infection. ${ }^{64}$

Turmeric is one among few clinically proven prominent immunomodulatory spice. ${ }^{65}$ Turmeric contains an essential oil, oleoresin, alkaloids and isolated compounds such as curcuminoids. Essential oil is composed of sesquiterpenes. The alkaloids responsible for aroma are turmerone, ar-turmerone and zingiberene. The active constituents of turmeric are curcuminoids and volatile oils including tumerone, atlantone and zingiberone. Yellow color of turmeric is due to presence of curcumonoids, the polyphenols. Major curcuminoids are curcumin, demethoxycurcumin, bisdemethoxycurcumin. ${ }^{66,67}$ Pure curcumin is insoluble in water. The bioavailability of oral curcumin is low because upto $65 \%$ of curcumin passes through GI tract. Absorbed curcumin is metabolized in intestine and liver.

Turmeric and its constituents are having a range of antioxidant activity such as capability to scavenge the primary radicals, repair and construction of lipid membrane aided by glutathione peroxidase. Churchill et al. ${ }^{68}$ studied the effect of curcumin on lymphocytes and found an increase in mucosal CD4(+) T-cells and B-cells in animals. Ramos et al. ${ }^{69}$ demonstrated that turmeric displayed $\mathrm{IC}_{50}$ of $<30 \mu \mathrm{g} /$ $\mathrm{ml}$ in the DPPH assay and $\mathrm{IC}_{50}$ of $<32 \mu \mathrm{g} / \mathrm{ml}$ in lipid peroxidation inhibition testing. The methanolic extract showed peroxynitrile scavenging activity with $\mathrm{IC}_{50} 17 \mu \mathrm{g} / \mathrm{ml} .{ }^{70}$ Boscaet al. ${ }^{71}$ showed a 45 days intake of hydroalcoholic extract of turmeric which resulted in decrease in the levels of serum lipid peroxides, which has a role in senescence and atheroscelorosis.

Turmeric is having potential anti-inflammatory activity. Due to its anti-inflammatory activity, turmeric is widely used in treating osteoarthritis. It has been found to block the production of certain prostaglandins and also have effects similar to cortisone and nonsteroidal anti- inflammatory drugs. Atkinson and Hunter ${ }^{72}$ reported the effect of turmeric extract in the treatment of steroid-dependent inflammatory bowel disease. The inhibitors of prostaglandin biosynthesis and NO production are potential anti-inflammatory and anti-cancer candidates. ${ }^{73}$ It was found that methanolic extracts inhibited prostaglandin E-2 production and NO formation towards inhibition of COX-2 and iNOS, respectively in mouse macrophages RAW264.7 cells.

Isolated compounds from turmeric such as curcumin is known to have anti-bacterial, anti-inflammatory, anti-cancer, anti-arthritic, hepatoprotective, anti hypercholesterolemic, chemoprotective and immunomodulatory activities. Another compound of turmeric, curcuminoids are also known to have several beneficial properties similar to curcumin. However, in this article we will summarize only immunomodulatory and anti-inflammatory functions. Curcuminoids are able to inhibit LPS induced production of TNF- $\alpha$, IL-1 $\beta$ and the activation of NF- $\kappa \mathrm{B}$ in human monocyte derived cells. ${ }^{74}$ Protease activated receptors (PARs) play a vital role in inflammation. Human leukemic mast cells (HMC1) co-express PAR2 and PAR4. A number of molecules involved in inflammation were inhibited by curcumin including phospholipases, lipoxygenase, COX 2, thrombaxane, prostaglandins, NO, TNF, IL- $12 .{ }^{75}$ The cytokine macrophage migration inhibitory factor is crucial factor in the pathogenesis of rheumatoid arthritis. ${ }^{76}$ Curcumin was found to be most potent inhibitor. The development of cell mediated immune response involves a complex network of cytokine signals generated by APCs or T helper (Th1 and Th 2) cells. Activated monocytes/macrophages release proinflammatory cytokines such as TNF- $\alpha$, IL- 1 and IL- 6 that play a role in immunity response. $^{67}$ Th1 cells secrete IL-2 and IFN- $\gamma$ which promote cell mediated immunity. Th2 cells secrete IL-4, IL-5, IL- 6 and transforming growth factor (TGF- $\beta$ ) that regulate humoral immunity. And negatively regulate cell mediated immunity. Curcumin inhibited TNF- $\alpha$ at a higher concentration. ${ }^{77}$ Kang et al. ${ }^{78}$ showed the inhibition of IL-12 production of murine macrophages stimulated with LPS. Macrophages treated with curcumin reduced the ability of antigen primed CD 4+ T-cells to produce IFN- $\alpha$ but increased the production of IL-4. Gao et al. ${ }^{79}$ showed that curcumin irreversibly inhibited expression of IL2 , IFN- $\gamma$ by mitogen stimulated splenic T-cells and IL- 12 production in peritoneal macrophages. Curcumin inhibited proinflammatory IL$1 \beta$, IL- 6 and TNF- $\alpha$ by bone marrow derived DCs stimulated with LPS and demonstrated that translocation of NF- $\kappa \mathrm{B}$ by curcumin was responsible for impairment of cytokine production. ${ }^{80}$ Srimal and Dhawan ${ }^{81}$ showed that curcumin is as potent as phenylbutazone in the carrageenan induced oedema test in the rats. Activated monocytes and macrophages release proinflammatory cytokines TNF, IL-1, IFN to induce inflammation. The process of inflammation involve production of prostaglandins, thromboxanes and leukotrienes-known as eicosanoids by macrophages and neutrophils. They are synthesized through arachidonic acid (AA) by COX2 or lipoxygenase (LOX). COX 2 is induced by inflammatory insult by cells. AA derived compounds are responsible to pain, inflammation, swelling and thrombosis. Hong et $a l .{ }^{82}$ showed inhibition of AA generation by curcumin. Huang et al..$^{83}$ also showed inhibition of AA in vitro, but the mechanism of inhibition is by both LOX and COX. Flynn et al. ${ }^{84}$ showed inhibition of 5 -HETE production by curcumin. Curcumin also was shown to inhibit the production of superoxide and $\mathrm{NO}$ by inflammatory cells thereby offering anti-inflammatory activity ${ }^{85}$ Curcumin has been shown to inhibit proinflammatory cytokines TNF, IL-1, IFN that play important role in anti-inflammatory activity. Curcumin's inhibitory effect on the NF- $\kappa B$ pathway is an example of its anti-inflammatory effect. It is shown to decrease metabolism of AA by downregulating the activity of lipoxygenase and COX 2 at transcriptional level. ${ }^{86,87}$ Curcumin has been shown to possess activity similar to TNF blockers, vascular endothelial cell growth factor blocker, human epidermal growth factor receptor blockers and HER2 blocker ${ }^{88}$ Curcumin was found to prevent the reduction of cytochrome enzyme $\mathrm{P} 450$ expression induced in inflammatory conditions. ${ }^{89} \mathrm{Curcumin}$ was further found to modulate proinflammatory cytokines expression, attenuate IL- $1 \beta$ TNBS- induced damage and increase IL-10 expression..$^{90}$ Curcumin scavenges reactive oxygen species produced by macrophages (super oxide anions, $\mathrm{H}_{2} \mathrm{O}_{2}$ and nitrite radicals) both in-vivo and in vitro in a study conducted on rat peritoneal macrophages. ${ }^{91}$ Curcumin also reduces the amount of reactive oxygen species generated in response to oxidative stress by downregulating iNOS activity in macrophages. ${ }^{92}$ Curcumin treatment reduced NO generation and protection of neural cells from oxidative stress and thus indirectly benefitting neuroinflammation protection associated with Alzheimers. ${ }^{93}$ Curcumin's free radical scavenging activity is responsible for anti-inflammatory properties. Pure curcuminoids I, II, III had strong antioxidant activity as determined by DPPH method ${ }^{94} \mathrm{~A}$ 
polyherbal formulation containing curcumin as one of the ingredients was found to reduce levels lipid peroxidation and increased levels of antioxidative enzymes. ${ }^{95}$ In summary, curcumin is shown to have effective DPPH scavenging, DMPD (+) scavenging, superoxide radical scavenging, hydrogen peroxide scavenging and ferrous $\mathrm{Fe}^{(2+)}$ chelating activities. ${ }^{96}$ Liu et al.${ }^{97}$ in a study conducted using bone marrow derived dendritic cells found that curcuma blocked STAT 3. Study on murine macrophage cells showed inhibition of IL-6, TNF- $\alpha$, PTGS-2 and reduction of $\mathrm{p} 38$ MAPK and increase of SOCS1 and SOCS3. ${ }^{98,99} \mathrm{BV}-2$ microglia cells treated with curcuma showed reduction in NF- $\kappa B$, iNOS and IL-6, TNF- $\alpha$, IL-1 $\beta$ levels. ${ }^{100}$ Further, Cianciulli et al. ${ }^{101}$ also reported reduction in iNOS, COX 2, HO-1, reduction in MAPK, NF- $\kappa \mathrm{B}, \mathrm{TNF}-\alpha$, NO, PGE-2 on same cells. Turmeric inhibited LPS induced IL-2, IL-1 $\beta$, IL- 6 and TNF- $\alpha$ and the phosphorylation of MAPK and NF- $\kappa B$ nuclear translocation. ${ }^{80,102}$

Studies conducted in-vivo on rats fed with dietary curcumin at $40 \mathrm{mg} /$ $\mathrm{kg}$, IgG levels were significantly increased after 5 weeks. ${ }^{103} \mathrm{IgG}$ molecules are antibodies produced initially upon infection of cell with pathogen. This shows that curcumin can induce IgG levels to fight against invading pathogen which explains its importance in imparting immunity. Cell mediated immunity in which antigen sensitized T-lymphocytes mediate the immune response against pathogens, rejection of organ transplants etc., Cell mediated immunity is measured by $\mathrm{T}$-cell proliferation, production of cytokines and $\mathrm{T}$ cells. Effect of curcumin on human T-cell proliferation showed that curcumin inhibited the isopentenyl pyrophosphate induced proliferation of cells. ${ }^{104}$

Clinical trials: Curcumin has long history of safe use. However, first clinical study was conducted in the year $2001^{105}$ with series of dosages, viz., $500 \mathrm{mg}, 1000 \mathrm{mg}, 2000 \mathrm{mg}, 4000 \mathrm{mg}$ and $8000 \mathrm{mg}$ daily for 3 months on patients. The study identified no treatment related toxicity upto $8000 \mathrm{mg}$ for 3 months. ${ }^{106}$ In yet another study, curcuminoids were given at a dose of $450 \mathrm{mg} .900 \mathrm{mg}, 1800 \mathrm{mg}$ and $3600 \mathrm{mg}$ per day upto 4 months on 15 patients with refractory colorectal cancer. The drug was found to be well tolerated. ${ }^{107}$ Phase-I clinical studies confirmed the safety of curcumin in humans for a period of 4 months.$^{105}$ Phase-II studies were conducted mainly to evaluate curcumin on treating chronic inflammation, malignancies. But the studies were on small group of patients. In a study conducted on 18 patients with rheumatoid arthritis, it was found that $1200 \mathrm{mg} /$ day curcumin showed improvement in rheumatoid symptoms. ${ }^{108} \mathrm{Heng}$ and colleagues ${ }^{109}$ reported topical use of curcumin in the treatment of active plaque lesions. After 3-4 weeks, six of six curcumin treated plaques improved by $25-70 \%$. Overall, turmeric and its metabolites have versatile biological activities in modulating immunity and anti-inflammation.

Fenugreek (Trigonella foenum-graecum L): Fenugreek is the ancient spice known since 4000 B.C. Fenugreek has spicy aroma, pungent bitter taste. Seeds are plant parts of economic importance. Essential oil and oleoresin is also obtained and are equally important. Seeds contain flavonoids, trigonelline, choline, gentianine and saponins. Essential oil contains $\beta$-pinene, camphor, $\beta$-caryophyllene and nerylacetate. Fenugreek's pharmacological importance has been well recognized. It is used to treat mouth ulcers, cancer. It is emollient, laxative and a vermifuge. Fenugreek is mainly used to treat diabetes ${ }^{23}$ and to treat dandruff and promote hair growth. The anti-hyperglycemic compound purified from fenugreek seeds was found to decrease lipid content of liver. ${ }^{110}$ Fenugreek and its active constituents could be useful in offering skin damage protection. ${ }^{111}$ Further, fenugreek is known to have strong antioxidant properties. ${ }^{112-114}$ Phenolics are known to have antioxidant properties which prevent lipid peroxidation. ${ }^{115}$ Aqueous extracts have normalized the levels in lipid peroxidation, oxidative stress in the liver, kidney. ${ }^{116}$ Kaviarasan et al. ${ }^{117}$ reported reduced levels of lipid peroxidation and increased activities of anti-oxidant enzymes in rats. An aqueous extract of germinated fenugreek extract has highest antioxidant activity, radical scavenging and inhibition of lipid peroxidation in mitochondrial preparation of rat liver. ${ }^{118}$ Fenugreek leaf powder supplementation greatly reduced oxidative stress in streptozotocin-induced diabetic rats. ${ }^{119}$ Lipid peroxidation was lowered and antioxidant enzymes activity was increased supporting fenugreek's antioxidant ability. Meera et al. ${ }^{120}$ reported hepatoprotective activities by ethanolic extracts against liver damage. The extract was also found to be exhibiting significant activity in superoxide radicals and NO radical scavenging. Immunomodulatory effect was reported on Zucker obese $(\mathrm{fa} / \mathrm{fa})$ rats when aqueous extracts were fed for 10 days. ${ }^{121}$ Aqueous extracts have also shown immunomodulatory effect on Swiss mice. ${ }^{122}$ Fenugreek exhibited significantly high phagocytic index indicating stimulation of reticulo-endothelial system. ${ }^{123}$ Methanolic extract showed significant increase in lymphocytes and T-cell rosette formation. Diabetic rats showed low activities of SOD, catalase, glutathione peroxidase and reduced glutathione in kidney which were restored to normal levels after treating with fenugreek oil. ${ }^{124}$ Fenugreek extract elicited increase in phagocytic index and phagocytic capacity of macrophages indicating immunostimulatory effect in Swiss albino male mice. ${ }^{122}$ The antioxidant property of fenugreek seeds might be contributing to protective effect on immunosuppressed mice, further, restoration of tissue antioxidant molecules by fenugreek extract was observed.

When rats were treated with fenugreek extract, inhibition of inflammation swelling was observed. ${ }^{25,126}$ Petroleum ether extracts of fenugreek indicated that fenugreek reduced $85 \%$ inflammation of the paw in formaldehyde and carrageenan induced paw oedema. ${ }^{127}$ Methanol extract inhibited production of phorbol-12-myristate-13acetate induced inflammatory cytokines in cultured THP-1 cells. ${ }^{111}$ In an adjuvant induced arthritis in albino rats, ethanol extract significantly decreased paw oedema and decreased levels of IL-1a, IL-1b, IL-2, IL-6 and TNF- $\alpha$. The extract also reduced levels of LPO and increased SOD and GSH levels in cartilage tissue. ${ }^{128}$ The extract showed significant analgesic and anti-inflammatory activity in carrageenan induced rat paw oedema as compared to diclofenac sodium. It was suggested that flavonoid component of extract has significant anti-inflammatory activity. ${ }^{129}$

Ginger (Zingiber officinale Roscoe): Ginger, like turmeric and chili pepper is very widely used spice in household. Ginger has warm, sweet, pungent and aromatic flavor. Rhizome is used fresh and dried ginger is used in spice mix. In addition to rhizome, essential oil and oleoresin are parts of medicinal importance. Major constituents of the essential oil are zingiberene and ar-curcumene. The pungent taste constituents are gingerols, shogaols and zingerone. One of the traditional uses of ginger is to treat dyspepsia and nausea, cough, stomach pain. In addition, ginger is known to have other health benefits such as antibacterial, antioxidant, anti-inflammatory, immunomodulatory, anti-ulcer, gastro protective, cholesterol lowering, antifungal. ${ }^{23}$ Ginger reduces release of prostaglandin and thromboxane in lung parenchyma suggesting its role in anti-inflammatory activity. ${ }^{130}$ Ginger inhibited NF- $\kappa$ B activation and diminished the secretion of vascular endothelial growth factor and IL8. Ginger with its 12 important compounds provide antioxidant activity 40 times higher than Vit-E. Dugasani et al. ${ }^{131}$ found that 6 -shogaol has potent antioxidant and anti-inflammatory activity. Ginger alkaloid 10 -gingerol is potent among gingerols. Ginger compounds protect lipid peroxidation in mouse liver hepatocytes. ${ }^{132}$ Treatment of rats with $1 \%$ dietary ginger was found to increase the activity of SOD, catalase, GPx, GR and glutathione thus suggesting its protective role. ${ }^{133}$ In another experiment, lindane administration enhanced lipid peroxidation and antioxidant defenses in male albino rats. But, ginger diet attenuated lipid peroxidation by modulating oxygen free radicals scavenging enzyme. ${ }^{134}$ In ginger diet doxorubicin treated rat groups, antioxidant parameters malondialdehyde(MDA), glutathione (GSH) levels and 
enzyme activities of glutathione S-transferase(GST), SOD, catalase, glutathione peroxidase $(\mathrm{GPx})$ were restored normally compared to control groups. ${ }^{135}$ Compounds isolated from ginger were found to significantly decrease lipopolysaccharide induced NO production and significantly reduced inducible NO synthase. ${ }^{136}$ Hexane extract was found to have anti-inflammatory properties because it can suppress transcription of inflammatory mediator genes through the MAPK and NF- $\kappa B$ signaling pathways. ${ }^{137}$ Ginger essential oil was studied for antioxidant activity. It exhibited strong antioxidant activity measured by DPPH of FRAP method. A component of ginger, (6)-paradol has chemoprotective and lipid peroxidation and antioxidant activity. ${ }^{138}$ Furthermore, (6)-gingerol exhibited preventive potential for the management of Alzheimer's disease through antioxidant activity. ${ }^{139}$ Ginger also exhibited neuroprotective effect by accelerating brain antioxidant defense mechanism. ${ }^{140}$

Several in vitro studies were reported on role of ginger and its metabolites in offering various pharmacological benefits. Stoilova et al. ${ }^{141}$ reported (9)(6)-dehydroshogaol, (6) shogaol and 1-dehydro (6)-gingerdione having good inhibitors of NO synthase in activated macrophages. Ginger extract also shown to have inhibited DPPH upto $90 \%$. Zingerone is effective scavenger of the free radicals like super oxide, peroxyl and peroxyl nitrite. ${ }^{142}$ Topical application of 6-gingerol inhibited TPA induced COX 2 expression and suppressed NF- $\kappa B$ DNA binding activity in mice skin. ${ }^{143}$ Essential oil and oleoresin were found to be better antioxidants than butylated hydroxyanisole. ${ }^{144}$ Ginger is known to relieve pain in osteoarthritis patients mainly due to its antiinflammatory activity. ${ }^{145}$ Ginger, like turmeric is known to have activity similar to non-steroidal anti-inflammatory drugs (NSAIDs) because it suppresses prostaglandin synthesis through inhibition of COX 1and COX $2 .{ }^{146}$ Ginger suppressed lymphocyte proliferation found in in-vitro study which was mediated by decrease in IL- 2 and IL-10 production. ${ }^{147}$ Ginger volatile oil significantly inhibited T-lymphocyte proliferation, decrease in the number of total lymphocytes and T-helper cells. It also inhibited IL-1 and secretion of the mice peritoneal macrophage. ${ }^{148}$

Several in-vivo studies were reported using ginger extracts to demonstrate its anti-inflammatory and immunomodulatory roles. A study conducted on 12-O-tetradecanoyl phorbol-13-acetate(TPA)treated female ICR mice and rats of the effect of 6-gingerol and 6-paradol, it was shown that ginger alkaloids have anti-inflammatory activity and suppressed the TNF- $\alpha$ production. ${ }^{143}$ Ginger extract significantly reduced elevated expression of NF- $\kappa$ B and TNF- $\alpha$ in rats with liver cancer. Ginger may act as an anti-cancer and antiinflammatory agent by inactivating NF- $\kappa B$ through the suppression of pro-inflammatory TNF- $\alpha$ (Habib2008). Essential oil showed to exert anti-inflammatory effect by preventing alterations of some cytokines/ inflammatory biomarkers - IL-6, IL-10 and TNF- $\alpha .{ }^{149}$ Improved humoral immunity was found in mice fed with $50 \%$ ethanolic ginger extract for seven days. ${ }^{150}$ Volatile oil may influence both cell mediated immune response and non-specific proliferation of T-lymphocyte. ${ }^{148}$ Essential oil suppressed chronic inflammation induced by formalin in kinin, carrageenan induced paw oedema and chronic oedema. ${ }^{151}$ It even inhibited chronic joint inflammation without any effects in initial acute phase of joint inflammation or granuloma formation at the site of Streptococcal cell wall deposition in liver. ${ }^{152}$

Human studies were carried out to evaluate ginger and its metabolites role. In a randomized double-blind placebo controlled study it was found that ginger can improve rheumatoid arthritis by decreasing disease manifestations via increasing Fox P3 genes expression and by decreasing RORyt and T-bet gene expression. ${ }^{153}$ In another study involving 25 patients, hydroalcoholic extract was shown to reduce expression of GATA-3, ROR-yt and T-bet in PBMCs of asthmatic patients. ${ }^{154}$
Black pepper (Piper nigrum L): Black pepper is an aromatic and pungent spice whose pungency differs from that of capsaicin. It also adds different flavor and taste. Pepper seeds are important parts of commercial use. Essential oil and oleoresin are obtained from seeds. Seeds contain alkaloid called piperine. The essential oil contains $\alpha$-pinene, $\beta$-pinene, $\beta$-caryophyllene, limonene as major constituents. The major alkaloids are piperine, brachymide B and others. Quercetin, isoquercetin, isorhamnetin, kaempferol are major flavanols found in pepper. Pepper is mainly used to stimulate taste buds, improve digestion and treating flatulence. Further, it is also having carminative property, antibacterial, antioxidant, anti-inflammatory and immunomodulatory activity. ${ }^{23}$ Important alkaloid, piperine has been shown to increase bioavailability. In a separate experiment, it was demonstrated that bioavailability of epigallo catechin-3-gallate (EGCG), a phenolic component of tea has improved when taken with piperine in mice. ${ }^{155}$ Piperine inhibits LPS induced endotoxin shock through inhibition of type I IFN production. ${ }^{156}$ It lowers lipid peroxidation in vivo and protects against oxidative damage by quenching free radicals and ROS. Piperine was shown to protect the plasmid DNA from degradation by gamma-radiation. ${ }^{157}$ Supplementation of diet with piperine in male Wistar rats lowered conjugated dienes and thiobarbituric acid reactive substances (TBARS) and maintained the levels of reduced glutathione (GSH) and antioxidative enzymes SOD, catalase, GPx, GST-indicating its role as an antioxidant. It was also found that supplementation of high fat diet with piperine protected erythrocytes from oxidative stress by improving antioxidant status in male Wistar rats. ${ }^{158}$ Different fractions of petroleum ether extracts of pepper have strong antioxidant activity. ${ }^{159}$ Essential oil and oleoresins also showed strong antioxidant capacity in comparison to BHA and BHT. ${ }^{160}$ Black pepper extracts inhibited by LPO by $45-85 \%$, COX enzymes by $31-80 \%$ and cancer cell proliferation by $3.5-86.8 \% .{ }^{16}$

Several in-vitro and in-vivo studies have been conducted in support of pepper's pharmacological activities. Pepper aqueous extract reduce up to $100 \%$ NO production by LPS-stimulated macrophages. ${ }^{39}$ Ethanol seed extract enhanced the proliferation of macrophage cell line J774a-1. ${ }^{16}{ }^{2}$ Piperine has exhibited anti-inflammatory activity. It reduced synthesis of prostaglandin $\mathrm{E}_{2}$ on IL- $1 \beta$ stimulated fibroblast like synoviocytes. ${ }^{163}$ Piperine treated mouse splenocytes exhibited an increase in the secretion of Th- 1 cytokines (IFN- $\gamma$ and IL-2), increased macrophage activation and proliferation of $\mathrm{T}$ - and $\mathrm{B}$ - cell. ${ }^{164}$ Piperine inhibited B-cell proliferation by causing GO/G1 phase cell cycle arrest and inhibited immunoglobulin's in mouse B cells. ${ }^{165}$ Piperine inhibited polyclonal antigen specific T-lymphocyte proliferation without affecting cell viability. Piperine also suppressed T-lymphocyte entry into the S and G2/M phase of cell cycle. ${ }^{166}$ Aqueous extracts enhanced splenocyte proliferation in experiments conducted on $\mathrm{BALB} / \mathrm{c}$ and $\mathrm{C} 57 / \mathrm{BL} 6$ mice. ELISA results revealed that pepper extracts significantly enhanced T-helper (Th1) cytokine release by splenocytes signifying its immunomodulatory activity. ${ }^{167}$ Piperine showed antiinflammatory activity in rats. It acted partially through stimulation of pituitary adrenal axis. Oxidative stress and apoptotic markers altered by cadmium toxicity were modulated by piperine in $\mathrm{BALB} / \mathrm{c}$ mice. Inhibition of cell proliferative response, alterations in T-cell and B-cell phenotypes, cytokines released and morphological changes were stored to normalcy. ${ }^{168}$

Based on findings from in vitro, in vivo and to certain extent human studies scientific evidence is available on the potential role of spices in offering both innate and adaptive immunity in humans. It is interesting to note that all spices which we have reviewed demonstrated reasonable evidence in providing immunity, anti-inflammatory and anti-oxidant activity. However, we did not find many human clinical trials. Documented evidence on human clinical trials was available on spices such as turmeric, coriandrum, cinnamonand ginger. Several other spices and condiments are also regularly consumed, a non-exhaustive 
list of them include- clove, sesame seeds(white and black), caraway seeds, bay leaves, white pepper, long pepper, star anise, Indian rose chestnut, fennel seeds, maceandcarom (bishop's weed).

\section{Spices might offer protection against SARS-CoV-2 infection}

Treatment for COVID-19 disease caused by SARS-Cov-2 is still uncertain. However, some of the anti-inflammatory treatments offered to rheumatology, existing anti-virals and antagonists for proinflammatory cytokinins are being considered (Table 4) as possible therapy in severe cases. Though, research efforts are under way worldwide to develop vaccine and treatment, it may be a while before they are available for treatment. It is now evident that COVID-19 has proximate association with innate and adaptive immune responses. The responses decline with age, nutrition and diseases. Roy et al. ${ }^{3}$ found that curcuminoids and $\mathrm{Zn}$, both considered as GRAS substances, identified as nutraceutical and nutrient, respectively have proven history of antiviral activity leading to release of prophylactic candidates against COVID-19. Curcumin, through inhibition of viral entry into cells, suppression of viral replication, modulation of cytokines, act as antiviral agent to inhibit Influenza Type A, Hepatitis A, Zika, HIV etc. ${ }^{3,4}$ Roy et al. ${ }^{3}$ conducted in silico studies and demonstrated that curcumin directly binds to receptor binding domain of viral spike proteins of SARS-CoV-2 virus to prevent virus entry. Further, in our assessment of published literature it was shown that curcumin inhibits release of abnormal cytokine storm aiding to control of COVID-19 progression. Manoharan et al. ${ }^{4}$ proposed that Curcumin acts as an attenuator via modulating the proinflammatory effects of AngiotensinII-AT1 receptor-signaling pathways to reduce respiratory distress. Jia et al. ${ }^{169}$ demonstrated that an emulsion made of curcumin as a topical application can prevent the SARS-CoV-2 infection. Therefore, research points to role of turmeric and its metabolites in controlling entry of virus and at later stages controlling release of abnormal cytokine release. In yet another interesting study, ${ }^{5}$ the authors have correlated data drawn from 163 countries during COVID-19 pandemic season. They have concluded that nations with higher consumption of spices have shown lesser COVID-19 cases and higher recovery rates compared to nations with lower spice consumption. Over 300 clinical trials have been reported on the beneficial effects of curcumin against various diseases such as Inflammatory diseases, neurological disorders, cardiovascular diseases, pulmonary diseases, cancer and so on. ${ }^{170}$ They have also reported suppression of pulmonary edema and fibrosin-associated pathways in COVID-19 infections. The evidences points to role of curcumin in controlling various diseases including COVID-19.

First line of defense against SARS-CoV-2 infection is the individual's innate immunity. Innate immunity is dependent on person's health and age in addition to nutrition status. Though exact treatment is not available but several options are proposed. We wish to discuss some of the proposed treatments:i) IL- 6 antagonists: IL- 6 acts as an inducer of proliferation and differentiation of immune cells. In COVID-19 patients, high levels of IL- 6 were detected. IL-6 and Janus Kinase (JAK) inhibitors were thought to be involved in inhibition of proinflammatory cytokines involved in 'cytokine storm'. Thus, by inhibiting IL-6 or JAK inhibitors cytokine storm can be controlled; ii) TNF- $\alpha$ inhibitors: TNF- $\alpha$ is one of the most potent proinflammatory cytokines. Levels of TNF- $a$ were found to be in elevated levels in serum of COVID-19 patients. TNF- $\alpha$ is involved in viral entry into host cell. ${ }^{7}$ It is hypothesized that TNF- inhibitors may be effective in blocking viral entry and detrimental effects of TNF- $\alpha$; iii) IL-17 blocker: IL-17 is one of the cytokines found abundantly in severe COVID-19 patients. IL17 is associated with severe lung inflammation and thus damages to tissue. Blocking IL-17 may be an effective treatment to reduce organ damage; iv) some of the NSAIDs reported to have direct antiviral effect on SARS-CoV-2 by interfering with viral RNA synthesis. Though, evidence is weak, NSAIDs such as indomethacin are being proposed in the treatment.

Upon infection immunoglobulin IgM is detected in patient's blood in 3-6 days and IgG after 8 days. ${ }^{171}$ It was found that levels of IgM and IgG progressively increased from day 7 to day 20 . Researchers also showed that 7-9 days after onset of symptoms, high concentrations of T helper cells (Th), NK and B cells were detected and it was concluded that early adaptive immune system may be related to better clinical outcome.

As we conclude from studies conducted on spices, scientific evidence is mounting on the role of spices such as capsicum, ginger, turmeric, black pepper and cinnamon bark in offering effective immunity. Capsicum found to have increased serum immunoglobulin concentrations (IgM and IgG). Almost all spices reviewed in the present report have inhibited proinflammatory cytokines, thus may be helping to reduce/ limit 'cytokine storm'. Spices like curcuma showed reduction in NF$\kappa B$, IL- $6^{98}$ inhibited TNF- $\alpha$, IL- $1 \beta$ and the activation of NF- $\kappa B$ in human monocyte derived cells. ${ }^{74}$ Curcumin essential oil inhibited NO synthase, IL-1 and IL-6, COX-2 thus showing evidence of curcumin's anti-inflammatory role. Turmeric was shown to inhibit a number

Table 4: Potential anti-inflammatory treatments currently available for COVID-19.7

\begin{tabular}{|c|c|c|c|}
\hline SI No & Treatment & Proposed mode of action & Reference \\
\hline 1 & Corticosteroids & $\begin{array}{l}\text { Corticosteroids are more likely to function on inflammation-mediated lung injury and } \\
\text { interstitial fibrosis at late-stage of Acute Respiratory Distress Syndrome }\end{array}$ & [172] \\
\hline 2 & Chloroquine and hydroxychloroquine & $\begin{array}{l}\text { By blocking the virus-receptor binding and virus-endosome fusion; } \\
\text { By increasing the activity of Treg }\end{array}$ & [7] \\
\hline 3 & $\begin{array}{l}\text { CQ, HCQ and intravenous immunoglobulin } \\
\text { (IVIg) }\end{array}$ & $\begin{array}{l}\text { By inhibitingthe production of cytokines in macrophages and the antigen presentation in } \\
\text { dendritic cells }\end{array}$ & [7] \\
\hline 4 & $\begin{array}{c}\text { Intravenous immunoglobulin (IVIg)- IVIg } \\
\text { is a blood product containing polyclonal } \\
\text { immunoglobulin G }\end{array}$ & $\begin{array}{l}\text { One of the proposed mechanisms is the interaction of IgG-Fc with Fc gamma receptors located } \\
\text { on immune cells, resulting in pleiotropic functional consequences including the expansion of } \\
\text { regulatory T cell population, phagocytosis, antibody-dependent cellular cytotoxicity (ADCC), } \\
\text { immune cell differentiation and maturation, apoptosis, expression of proinflammatory } \\
\text { cytokines and antigen-presentation }\end{array}$ & [7] \\
\hline 5 & $\begin{array}{l}\text { Interleukin (IL)- } 6 \text { antagonists, granulocyte } \\
\text { colony-stimulating factor (GM-CSF) } \\
\text { inhibitor, IL-1 antagonists, IL-17 antagonists } \\
\text { and antitumor necrosis factor (TNF) agents }\end{array}$ & By limiting Cytokine storm & [7] \\
\hline 6 & Janus kinase (JAK) inhibitors & By inhibiting many proinflammatory cytokines involved in cytokine storm of COVID-19 & [7] \\
\hline 7 & Anti-TNF agents & By blocking viral entry and detrimental effects of exuberant TNF- $\alpha$ & [7] \\
\hline 8 & Anti-IL-17 antagonists & By blocking induction of proinflammatory cytokines & [7] \\
\hline
\end{tabular}


of molecules involved in inflammation including phospholipases, lipoxygenase, COX-2, thrombaxane, prostaglandins, NO, TNF and IL-12. Curcumin inhibited proinflammants IL-1 $\beta$, IL- 6 and TNF- $\alpha$ by bone marrow derived dendritic cells. Using bone marrow dendritic cells it was found that curcuma blocked STAT 3. Inhibition of Janus kinase (JAK)-signal transducer and activator of transcription (STAT) pathway (JAK/STAT) attenuates cytokine storm. These results suggest that spices have a role in inhibiting and or reducing proinflammatory cytokines levels.

In COVID-19 patients there is a marked decrease in levels of $\mathrm{CD} 4^{+}$cells, $\mathrm{CD}^{+}$cells, B-cells and NK cells as well as decrease in monocytes, eosinophils and basophils. Further, there is an increase in proinflammatory cytokines such as IL-6, IL-1 $\beta$, IL-2, IL-8, IL-17, G-CSF, GM-CSF and TNF- $\alpha$ (called cytokine storm). ${ }^{11}$ Moreover, SARS-CoV-2 increases IKB (inhibitor of nuclear factor $\kappa \mathrm{B}$ ) degradation leading to the activation of NF- $\kappa B$ signaling and induce IL- 6 and TNF- $\alpha$. Specific blockage of TNF- $\alpha$ and IL- 6 antagonists can attenuate inflammation processes; similarly inhibition of JAK/STAT pathway attenuates cytokine storm. Inhibition of NFkB attenuates TNF- $\alpha$ and IL-6 expression. In the present report, most of the spices which we have reviewed have shown to regulate inflammation process, inhibit proinflammatory cytokines and abnormal cytokine release. This is true in case of turmeric and its alkaloids.

In addition, spices have also proven ability as strong antioxidants, free radical scavengers, inhibition of arachidonic acid compounds (responsible for pain, inflammation, swelling, thrombosis) via LOX and COX pathway. All spices reviewed in the present report have shown antioxidant activity by way of DPPH radical scavenging activity, lipoxygenase inhibition, phospholipid peroxidation, hydroxyl radical scavenging activity, superoxide dismutase activity and anti-lipid peroxidation. Owing to the presence of phenolics and flavonoids many of the spices reviewed in the present report have antioxidant activity superior to or equivalent to ascorbic acid. These are responsible in neutralizing invading pathogen. Taken together, spices when consumed daily can have beneficial effects on innate as well as adaptive immunity to human body which gives protection against diseases including COVID-19.

\section{CONCLUSION}

Evidence generated from the published literature is compelling to arrive at a conclusion that consumption of spices can improve both innate and adaptive immunity. The developed immunity can potentially fight various diseases including COVID-19. Several clinical trials are in various phases of evaluation to find the role of spices in offering immunity against COVID-19. It is interesting to wait for outcome of clinical trials (Table 3 ) conducted using spices or products with spice ingredients. The results might be available in the first -second quarter of 2021 to the scientific community. While there is strong evidence on role of spices as immunomodulators and anti-inflammatory agents, we did not find many studies on humans. In our opinion, it is observed that spices are consumed as a part of diet on a daily basis since several years, it may not take huge business sense, apparently researchers and industries are not interested in carrying out human clinical studies on par with pharmaceuticals or biopharmaceuticals. Scientifically also it may be challenging to take Ethics committee approval to find human subjects, in such studies who consume food without spices, for comparison. However, innovative methods of those who consume lesser amount of spices against those who consume higher amounts could be one approach. Addition of selected spices in a superiority trial would be another approach. Also, it would be of great scientific interest if population studies are conducted to document consumption of spices and the populations' immune status. An adequately large sample of population may be assessed for their immune status by analyzing their blood for immunity bio-markers. Such studies could be conducted in partnership with Governmental organizations. In the past decade, there has been greater understanding on human body's immunity with the advent state-of-the-art techniques. With the result, biomarkers have been made available with validated testing methods that were lacking in earlier decades. Hence, it is reasonable to recommend that more human studies on spices and immunity should be conducted to promote healthy living.

\section{ACKNOWLEDGEMENT}

We acknowledge support from Aurvidye Trust, Bangalore. We also thank Mr. Sharanbasappa Durg for his help in supporting clinical trial research data from various databases.

\section{AUTHOR CONTRIBUTIONS}

DBAN designed the review, TSJ collected literature, DBAN and TSJ together drafted the work, DBAN reviewed the work.

\section{FUNDING/SUPPORT}

No external funds supported this work.

\section{DECLARATION OF INTEREST}

The authors have no relevant interests to declare.

\section{REFERENCES}

1. Narayana DBA, Johnson ST. Regulations for manufacturing traditional foods-global and regional challenges. In: Nutritional and Health Aspects of Food in South AsianCountries,Academic Press, 2020; pp. 297-307.

2. Coelho-RavagnaniCdF, Corgosinho FC, etal. Dietary recommendations during the COVID-19 pandemic. Nutrition Rev. nuaa067, 2020;https:// doi.org/10.1093/nutrit/nuaa067.

3. Roy A, Sarkar B, Celik C, et al. Can concomitant use of zinc and curcumin with other immunity-boosting nutraceuticals be the arsenal against COVID-19? Phytother Res. 2020; doi:10.1002/ptr.6766

4. Manoharan Y,Haridas V, Vasanthakumar KC. Curcumin: a Wonder Drug as a Preventive Measure for COVID-19 Management. Ind J Clin Biochem. 2020; 35:373-375.

5. Elsayed Y, Khan NA. Immunity-Boosting Spices and the Novel Coronavirus. ACS Chemical Neuroscience. 2020;1696-1698.

6. Shi $Y$, Wang $Y$, Shao $C$, et al. COVID-19 infection: the perspectives on immune responses. Cell Death Differentiation. 2020;27:1451-1454.

7. Tufan A, Güler AA, Matucci-Cerinic M. COVID-19, immune system response, hyperinflammation and repurposing antirheumatic drugs. Turk J Med Sci. 2020;50: 620-632.

8. Sun $T, X u Z, W u C T$, et al. Antioxidant activities of different colored sweet bell peppers (Capsicum annuum L.). J Food Sci. 2007;72:S98-S102.

9. Takano F, Yamaguchi M, Takada S, et al. Capsicum ethanol extracts and capsaicin enhance interleukin-2 and interferon-gamma production in cultured murine Peyer's patch cells ex vivo. Life Sci.2007;80:15531563.

10. Beltran J, Ghosh AK, Basu S. Immunotherapy of tumors with neuroimmune ligand capsaicin. J Immunol. 2007; 178:3260-3264.

11. Granato $M$, GilardiniMontani MS, Filardi $M$, et al. Capsaicin triggers immunogenic PEL cell death, stimulates DCs and reverts PEL-induced immune suppression. Oncotarget. 2015; 6:29543-29554.

12. Fischer BS, Qin D, Kim K, McDonaldTV.. Capsaicin inhibits Jurkat T-cell activation by blocking calcium entry current I (CRAC). J Pharmacol Exp Ther. 2001; 299:238-246.

13. Hazekawa M, Hideshima Y, Ono K, et al. Anti-inflammatory effects of water extract from bell pepper (Capsicum annuum L. var. grossum) leaves in vitro. Exp. Ther. Med. 2017; 14:4349-4355. 
14. Antonious GF, Kochhar TS, Jarret RL, Snyder JC. Antioxidants in hot pepper: variation among accessions. J Environ Sci Health B.2006; 41:1237-1243.

15. Jolayemi AT, Ojewole JA. Comparative anti-inflammatory properties of Capsaicin and ethyl-aAcetate extract of Capsicum frutescens Linn [Solanaceae] in rats. Afr Health Sci. 2013; 13:357-361.

16. Sancho R, Lucena C, Macho A, et al. Immunosuppressive activity of capsaicinoids: capsiate derived from sweet peppers inhibits NFkappaB activation and is a potent antiinflammatory compound in vivo. Eur J Immunol. 2002; 32:1753-1763.

17. Santoni G, Perfumi M, Birarelli P, etal. Invivo capsaicin treatment inhibits rat NK cell cytotoxic functions. Immunopharmacollmmunotoxicol. 1995; 17:511-528.

18. Santoni G, Perfumi M, Bressan AM, Piccoli M. Capsaicin-induced inhibition of mitogen and interleukin-2-stimulated $T$ cell proliferation: its reversal by in vivo substance $\mathrm{P}$ administration. J. Neuroimmunol. 1996; 68:131-138.

19. Jang HY, Kim SM, Yuk JE, et al. Capsicum annuum L. methanolic extract inhibits ovalbumin-induced airway inflammation and oxidative stress in a mouse model of asthma. J Med Food.2011; 14:1144-1151.

20. Hernández-Ortega M, Ortiz-Moreno A, Hernández-Navarro MD, et al. Antioxidant, antinociceptive and anti-inflammatory effects of carotenoids extracted from dried pepper (Capsicum annuum L.). J Biomed Biotechnol.2012:Article ID:524019.

21. Nilsson G, Ahlstedt S. Altered lymphocyte proliferation of immunized rats after neurological manipulation with capsaicin. Int J Immunopharmacol. 1988; 10:747-751.

22. Yu R, Park JW, Kurata T, Erickson KL. Modulation of select immune responses by dietary capsaicin. Int J VitamNutr Res. 1998; 68:114119.

23. Charles DJ. 2013. Antioxidant Properties of Spices, Herbs and Other Sources. Springer, NY. pp. 1-610.

24. Bhat J, Damle A, Vaishnav PP, et al. In vivo enhancement of natural killer cell activity through tea fortified with Ayurvedic herbs. Phytother Res. 2010; 24:129.

25. Sengupta A, Ghosh S, Bhattacharjee S. Dietary cardamom the formation of azoxymethane-induced aberrant crypt foci in mice and reduces COX-2 and iNOS expression in the colon. Asian Pac J Cancer Prev. 2005; 6:118-122.

26. Bhattacharjee S, Rana T, Sengupta A. Inhibition of lipid peroxidation and enhancement of GST activity by cardamom and cinnamon during chemically induced colon carcinogenesis in Swiss albino mice. Asian Pac J Cancer Prev.2007; 8:578-582.

27. Misharina TA, Terenina MB, Krikunova NI. .PriklBiokhimMikrobiol. 2009; 45:710-716.

28. Ho SC, TsaiTH, Tsai PJ, Lin CC. Protective capacities of certain spices against peroxynitrite-mediated biomolecular damage. Food Chem Toxicol. 2008; 46:920-928.

29. Suganthi R, Rajamani S, Ravichandran MK, Anuradha CV. Effect of food seasoning spices mixture on biomarkers of oxidative stress in tissues of fructose-fed insulin-resistant rats. J Med Food.2007;10:149-153.

30. Yadav AS, Bhatnagar D. Free radical scavenging activity, metal chelation and antioxidant power of some of the Indian spices. Biofactors2007;31:219-227.

31. Nair S, Nagar R, Gupta R. Antioxidant phenolics and flavonoids in common Indian foods. J Assoc Physicians India.1998;46:708-710.

32. Nanasombat, S., Wimuttigosol, P. Antimicrobial and antioxidant activity of spice essential oils. Food Sci Biotechnol 2011;20: 45-53.

33. Saeed A, Sultana B, Anwar F, et al. Antioxidant and Antimutagenic Potential of Seeds and Pods of Green Cardamom (Elettaria cardamomum). Int. J. Pharmacol2014;10:461-469.

34. Raksamiharja R, Khairunnisa Sy, Zulharini MS, et al. Elettaria cardamomum Distillate Increases Cellular Immunity in Doxorubicin Treated Rats. Indones. J. Cancer Chemoprevent. 2012;3:437-443.

35. Al-Zuhair H, el-Sayeh B, Ameen HA, al-Shoora H. Pharmacological studies of cardamom oil in animals. Pharmacol Res. 1996;34:79-82.
36. Anand P, Murali KY, Tandon V, et al. Insulinotropic effect of cinnamaldehyde on transcriptional regulation of pyruvate kinase, phosphoenolpyruvate carboxykinase and GLUT4 translocation in experimental diabetic rats. Chem Biol Interact. 2010;186:72-81.

37. Tsai PJ, Tsai TH, Yu CH, Ho SC. Evaluation of NO-suppressing activity of several Mediterranean culinary spices. Food Chem Toxicol. 2007;45:440-447.

38. Panickar KS, Polansky MM, Anderson RA. Cinnamon polyphenols attenuate cell swelling and mitochondrial dysfunction following oxygen-glucose deprivation in glial cells. Exp Neurol. 2009;216:420427.

39. Jayaprakasha GK, Jagan Mohan Rao L, Sakariah KK. Volatile constituents from Cinnamomum zeylanicum fruit stalks and their antioxidant activities. J Agric Food Chem.2003;51:4344-4348.

40. Jayaprakasha GK, Ohnishi-Kameyama M, Ono H, et al. Phenolic constituents in the fruits of Cinnamomum zeylanicum and their antioxidant activity. J Agric Food Chem.2006;54:1672-1679.

41. Kim DH, Kim CH, Kim MS, et al. Suppression of age-related inflammatory NF-kappaB activation by cinnamaldehyde. Biogerontology2007;8:545-554.

42. Ricardo Gomez-Flores, Hernández-Martínez H, Tamez-Guerra P. Antitumor and immunomodulating potential of Coriandrum sativum, Piper nigrum and Cinnamomum zeylanicum. J. Natural Products2010;3:54-63

43. Tsai T-H, Huang W-C, Lien T-J, et al. Clove extract and eugenol suppress inflammatory responses elicited by Propionibacterium acnes in vitro and in vivo. Food Agricult. Immunol. 2017;28:916-931.

44. Lee BJ, Kim YJ, Cho DH, Sohn NW, Kang H. Immunomodulatory effect of water extract of cinnamon on anti-CD3-induced cytokine responses and p38, JNK, ERK1/2 and STAT4 activation. Immunopharmacollmmunotoxicol. 2011a;33:714-722.

45. Huss U, Ringbom T, Perera $P$, et al. Screening of ubiquitous plant constituents for COX-2 inhibition with a scintillation proximity based assay. J Nat Prod. 2002;65:1517-1521.

46. Gruenwald J, Freder J, Armbruester N. Cinnamon and health. Crit Rev Food Sci Nutr. 2010;50:822-834.

47. Balekar N, Bodhankar S, Mohan V, et al. Modulatory activity of a polyphenolic fraction of Cinnamomum zeylanicum L. bark on multiple arms of immunity in normal and immunocompromised mice. J.Appl. Pharmaceu.Sci. 2014;4:114-122.

48. Niphade SR, Asad M, Chandrakala GK, et al. Immunomodulatory activity of Cinnamomum zeylanicum bark. Pharmaceu. Biol. 2009;47:1168-1173.

49. Mehta A, Mehta S, Thakurdesai P. Efficacy and safety of standardized cinnamon bark extract for the prevention of chemotherapy-induced weight loss and alopecia in patients with breast cancer: a randomized, double-blind and placebo-controlled Study. Asian J Pharm Clin Res.2019;12:163-168.

50. Wangensteen $\mathrm{H}$, Samuelsen AB, Malterud KE. Antioxidant activity in extracts from coriander. Food Chemistry2004;88:293-297.

51. Sreelatha S, Padma PR, Umadevi M. Protective effects of Coriandrum sativum extracts on carbon tetrachloride-induced hepatotoxicity in rats. Food Chem Toxicol. 2009;47:702-708.

52. Satyanarayana S, Sushruta K, Sarma GS, et al. Antioxidant activity of the aqueous extracts of spicy food additives--evaluation and comparison with ascorbic acid in in-vitro systems. J Herb Pharmacother. 2004;4:1-10.

53. Wu TT, Tsai CW, Yao HT, et al. Suppressive effects of extracts from the aerial part of Coriandrum sativum L. on LPS-induced inflammatory responses in murine RAW 264.7 macrophages. J Sci Food Agric. 2010;90:1846-1854.

54. Kim IS, Yang MR, Lee OH, Kang SN. Antioxidant activities of hot water extracts from various spices. Int J Mol Sci. 2011;12:4120-4131.

55. Pandey A, Bigoniya P, Raj V, Patel KK.. Pharmacological screening of Coriandrum sativum Linn. for hepatoprotective activity. J Pharm Bioallied Sci.2011;3:435-441. 
56. Melo EA, Filho JM, Guerra NB. Characterization of antioxidant compounds in aqueous coriander extract (Coriandrum sativum L.). Lebensm.-Wiss. u.-Technol. 2005;38:15-19.

57. Cherng, J-M, Chiang W, Chiang L-C. Immunomodulatory activities of common vegetables and spices of Umbelliferae and its related coumarins and flavonoids. Food Chem. 2008;106: 944-950.

58. Msaada K, BenJemia M, Salem N. Antioxidant activity of methanolic extracts from three coriander (Coriandrum sativum L.) fruit varieties. Arabian J. Chem. 2017;10: S3176-S3183.

59. SritiJ,Bettaieb I, Bachrouch O, et al. Chemical composition and antioxidant activity of the coriander cake obtained by extrusion. J Essent Oil Res. 2011;23:7

60. Mandal S, Mandal M. Coriander (Coriandrum sativum L.) essential oil: Chemistry and biological activity. Asian Pac J Trop Biomed. 2015;5: 421-428.

61. Al-Mofleh IA, Alhaider AA, Mossa JS, et al. Protection of gastric mucosal damage by Coriandrum sativum L. pretreatment in Wistar albino rats. Environ ToxicolPharmacol.2006; 22:64-69.

62. Gupta S, Raghuvanshi M, Jain D. Comparative studies on antiinflammatory activity of Coriandrum sativum. Asian J. Exp. Biol. Sci. 2010; 1:151-154.

63. LiY, Wang J, Liu Y, et al. Antiviral and virucidal effects of curcumin on transmissible gastroenteritis virus in vitro. J Gen Virol. 2020;10.1099/ jgv.0.001466

64. Reuter J, Huyke C, Casetti F,et al. Anti-inflammatory potential of a lipolotion containing coriander oil in the ultraviolet erythema test. J Dtsch Dermatol Ges.2008; 6:847-851

65. Lele. R.D. Ayurveda and Modern Medicine. Bharatiya Vidya Bhavan, Mumbai, 400007. 2001

66. Sarker SD, Nahar L. Bioactivity of turmeric. In: Ravindran PN et al. (eds) Turmeric-the genus curcuma.CRC Press,NY. 2007;257-295

67. Gautam SC, Gao X, Dulchavsky S. Immunomodulation by curcumin. In: Aggarwal et al. (eds) The molecular targets and therapeutic uses of curcuminin health and disease, Springer, NY. 2007;321-34.

68. Churchill M, ChadburnA, Bilinski RT, Bertagnolli MM. Inhibition of intestinal tumors by curcumin is associated with changes in the intestinal immune cell profile. J Surg Res.2000;89:169.

69. Ramos A, Visozo A, Piloto J, et al. Screening of antimutage-nicity via antioxidant activity in Cuban medicinal plants. J. Ethnopharmacol. 2003;87: 241-246.

70. Kim JE, Kim AR, Chung HY, et al.In vitro peroxynitrite scavenging activity of diarylheptanoids from Curcuma longa. PhytotherRes.2003;17:481-484.

71. Bosca AR, Soler A, Gutierrez MAC, et al. Antioxidant Curcumaextracts decrease the blood lipid peroxide levels of human subjects. Age1995;18:167-169.

72. Atkinson RJ, Hunter JO. A double blind, placebo controlled randomised trial of Curcuma extractin the treatment of steroid dependent inflammatory bowel disease. Gastroenterology 2003;124: A205-A205.

73. Hong $\mathrm{CH}$, Hur SK, Oh OJ, et al. Evaluation of natural products on inhibition of inducible cyclooxygenase (COX-2) and nitric oxide synthase (iNOS) in cultured mouse macrophage cells. J. Ethnopharmacol. 2002;83:153-159.

74. Atmadja L, Ito W, Baker $Y$, et al. Effect of Curcuminoids as AntiInflammatory Agents on the Hepatic Microvascular Response to Endotoxin, Shock 2002;17:399-403.

75. Chainani-Wu N. Safety and anti-inflammatory activity of curcumin: a component of tumeric (Curcuma longa). J Altern Complement Med. 2003;9:161-168.

76. Molnar V, Garai J.Plant-derived anti-inflammatory compounds affect MIF tautomerase activity. Int Immunopharmacol.2005;5:849-856.

77. Chan MM. Inhibition of tumor necrosis factor by curcumin, a phytochemical. BiochemPharmacol.1995;49:1551-1556.

78. Kang BY, Chung SW, Chung W, et al.Inhibition of interleukin-12 production in lipopolysaccharide-activated macrophages by curcumin. Eur J Pharmacol. 1999;384:191-195.
79. Gao X, Kuo J, Jiang H, et al. Immunomodulatory activity of curcumin: suppression of lymphocyte proliferation, development of cell-mediated cytotoxicity and cytokine production in vitro. BiochemPharmacol. 2004;68:51-61.

80. Kim GY, Kim KH, Lee SH, et al. Curcumin inhibits immunostimulatory function of dendritic cells: MAPKs and translocation of NF-kappa B as potential targets. Jlmmunol.2005;174:8116-8124.

81. Srimal RC, Dhawan BN. Pharmacology of diferuloyl methane (curcumin), a non-steroidal anti-inflammatory agent. J Pharm Pharmacol. 1973;25:447-452.

82. Hong J, Bose M, Ju J, et al. Modulation of arachidonic acid metabolism by curcumin and related beta-diketone derivatives: effects on cytosolic phospholipase $A(2)$, cyclooxygenases and 5-lipoxygenase. Carcinogenesis2004;25:1671-1679.

83. Huang MT, Lysz T, Ferraro T, Abidi TF, Laskin JD, Conney AH. Inhibitory effects of curcumin on in vitro lipoxygenase and cyclooxygenase activities in mouse epidermis. CancerRes.1991; 51:813-819.

84. Flynn DL, Rafferty MF, Boctor AM. Inhibition of human neutrophil 5-lipoxygenase activity by gingerdione, shogaol, capsaicin and related pungent compounds. Prostaglandins Leukot Med. 1986; 24:195-198.

85. Bhaumik S, Jyothi MD, Khar A. Differential modulation of nitric oxide production by curcumin in host macrophages and NK cells. FEBS Lett. 2000; 483:78-82.

86. Oh SW, Cha JY, Jung JE, et al. Curcumin attenuates allergic airway inflammation and hyper-responsiveness in mice through NF-kB inhibition. J Ethnopharmacol. 2011; 136:414-421

87. Zhong F, Chen $H$, Han L, Jin $Y$, Wang W. Curcumin attenuates lipopolysaccharide-induced renal inflammation. Biol Pharm Bull. 2011; 34:226-232.

88. Aggarwal BB, Sundaram C, Malani N, Ichikawa H. Curcumin: the Indian solid gold. Adv Exp Med Biol. 2007; 595:1-75.

89. MasubuchiY, Enoki K, Horie T. Down-regulation of hepatic cytochrome P450 enzymes in rats with trinitrobenzene sulfonic acid-induced colitis. Drug MetabDispos. 2008; 36:597-603.

90. Jian YT, Wang JD, Mai GF, Zhang YL, Lai ZS. Di Yi Jun Yi Da XueXue Bao. 2004;24:1353-1358.

91.Joe B, Lokesh BR. Role of capsaicin, curcumin and dietary n-3 fatty acids in lowering the generation of reactive oxygen species in rat peritoneal macrophages. BiochimBiophys Acta. 1994; 1224:255-263

92. Chan MM, Huang HI, Fenton MR, Fong D. In vivo inhibition of nitric oxide synthase gene expression by curcumin, a cancer preventive natural product with anti-inflammatory properties. BiochemPharmacol. 1998; 55:1955-1962.

93. Jung KK, Lee HS, Cho JY, et al. Inhibitory effect of curcumin on nitric oxide production from lipopolysaccharide-activated primary microglia. Life Sci.2006; 79:2022-2031.

94. Naidu MM, Shyamala BN, Manjunatha JR, Sulochanamma G, Srinivas P.Simple HPLC method for resolution of curcuminoids with antioxidant potential. J Food Sci. 2009; 74:C312-C318.

95. Patel SS, Shah RS, Goyal RK. Antihyperglycemic, antihyperlipidemic and antioxidant effects of Dihar, a polyherbal ayurvedic formulation in streptozotocin induced diabetic rats. Indian J Exp Biol. 2009; 47:564570.

96. Ak T, Gülçin I. Antioxidant and radical scavenging properties of curcumin. Chem Biol Interact. 2008; 174:27-37.

97. Liu L, Liu YL, Liu GX, et al. Curcumin ameliorates dextran sulfate sodium-induced experimental colitis by blocking STAT3 signaling pathway. Int Immunopharmacol. 2013; 17:314-320.

98. Duncan SA, Baganizi DR, Sahu R, Singh SR, Dennis VA. SOCS Proteins as Regulators of Inflammatory Responses Induced by Bacterial Infections: A Review. Front Microbiol. 2017; 8:2431.

99. Catanzaro M, Corsini E, Rosini M, Racchi M, Lanni C. Immunomodulators Inspired by Nature: A Review on Curcumin and Echinacea. Molecules. 2018; 23:2778.

100. Castro CN, BarcalaTabarrozzi AE, Winnewisser J, et al. Curcumin ameliorates autoimmune diabetes. Evidence in accelerated murine models of type 1 diabetes. Clin Exp Immunol. 2014;177:149-160. 
101. Cianciulli A, Calvello R, Porro $C$, et al. PI3k/Akt signalling pathway plays a crucial role in the anti-inflammatory effects of curcumin in LPS-activated microglia. Int Immunopharmacol. 2016; 36:282-290.

102. Jagetia GC, Aggarwal BB. "Spicing Up" of the Immune System by Curcumin. J. Clin Immunol.2007; 27:19-35.

103. South EH, Exon JH, Hendrix K. Dietary curcumin enhances antibody response in rats. Immunopharmacollmmunotoxicol. 1997; 19:105119.

104. Cipriani B, Borsellino G, Knowles H, et al. Curcumin inhibits activation of Vgamma9Vdelta2 $\mathrm{T}$ cells by phosphoantigens and induces apoptosis involving apoptosis-inducing factor and large scale DNA fragmentation. J Immunol. 2001; 167:3454-3462.

105. Hsu C-H, Cheng A-L. Clinical studies with curcumin, In: Aggarwal $\mathrm{BB}$ et al. eds. The Molecular Targets and Therapeutic Uses of Curcumin in Health and Disease, NY, Springer. 2007; pp. 471-480.

106. Cheng AL, Hsu CH, Lin JK, et al. Phase I clinical trial of curcumin, a chemopreventive agent, in patients with high-risk or pre-malignant lesions. Anticancer Res.2001;21:2895-2900.

107. Sharma RA, Gescher AJ, Steward WP. Curcumin: the story so far. Eur J Cancer.2005; 41:1955-1968.

108. Deodhar SD, Sethi R, Srimal RC. Preliminary study on antirheumatic activity of curcumin (diferuloyl methane). Ind J Med Res. 1980; 71:632-634.110.

109. Heng MC, Song MK, Harker J, Heng MK. Drug-induced suppression of phosphorylase kinase activity correlates with resolution of psoriasis as assessed by clinical, histological and immunohistochemical parameters. Br J Dermatol. 2000; 143:937949

110. Moorthy R, Prabhu KM, Murthy PS. Mechanism of anti-diabetic action, efficacy and safety profile of Gll purified from fenugreek (Trigonella foenum-graceum Linn.) seeds in diabetic animals. Indian J Exp Biol. 2010; 48:1119-1122.

111. Kawabata T, Cui MY, Hasegawa T, et al. Anti-inflammatory and anti-melanogenic steroidal saponin glycosides from Fenugreek (Trigonella foenum-graecum L.) seeds. Planta Med. 2011; 77:705710.

112. Tripathi UN, Chandra D. Anti-hyperglycemic and anti-oxidative effect of aqueous extract of Momordica charantia pulp and Trigonella foenum graecum seed in alloxan-induced diabetic rats. Ind $\mathrm{J}$ BiochemBiophys. 2010; 47:227-233.

113. Xue W, Lei J, Li X, Zhang R. Trigonella foenum graecum seed extract protects kidney function and morphology in diabetic rats via its antioxidant activity. Nutr Res. 2011; 31:555-562

114. Marathe SA, Rajalakshmi V, Jamdar SN, Sharma A. Comparative study on antioxidant activity of different varieties of commonly consumed legumes in India. Food Chem Toxicol. 2011; 49:20052012.

115. Chatterjee S, Variyar PS, Sharma A. Stability of lipid constituents in radiation processed fenugreek seeds and turmeric: role of phenolic antioxidants. J Agric Food Chem.2009; 57: 9226-9233.

116. Anuradha $C V$, Ravikumar P. Restoration on tissue antioxidants by fenugreek seeds (Trigonella foenum graecum) in alloxan-diabetic rats. Ind J Physiol.Pharmacol.2001; 45: 408-420.

117. Kaviarasan S, Sundarapandiyan R, Anuradha CV. Protective action of fenugreek (Trigonella foenum graecum) seed polyphenols against alcohol-induced protein and lipid damage in rat liver. Cell Biol Toxicol. 2008; 24:391-400.

118. Dixit P, Ghaskadbi S, Mohan H, Devasagayam TP. Antioxidant properties of germinated fenugreek seeds. Phytother Res. 2005; 19:977-983

119. Annida B, StanelyMainzen Prince P. Supplementation of fenugreek leaves reduces oxidative stress in streptozotocin-induced diabetic rats. J Med Food. 2005; 8:382-385

120. Meera R, Devi P, Kameswari B, et al. Antioxidant and hepatoprotective activities of Ocimumbasilicum Linn. and Trigonella foenumgraecum Linn. against $\mathrm{H} 2 \mathrm{O} 2$ and CCL4 induced hepatotoxicity in goat liver. Indian J Exp Biol. 2009; 47:584-590.
121. Raju J, Bird RP. Alleviation of hepatic steatosis accompanied by modulation of plasma and liver TNF-alpha levels by Trigonella foenum graecum (fenugreek) seeds in Zucker obese (fa/fa) rats. Int J Obes (Lond).2006;30:1298-1307.

122. Bin-Hafeez B, Haque R, Parvez S, et al. Immunomodulatory effects of fenugreek (Trigonella foenum graecum L.) extract in mice. Int Immunopharmacol. 2003; 3:257-265.

123. TripathiT, Maurya AK, Kahrana M, et al. Immunomodulatory property of ethanolic extract of Trigonella foenum-graeceum leaves on mice. Der Pharmacia Lettre. 2012; 4:708-713

124. Hamden K, Masmoudi H, Carreau S, et al. Immunomodulatory, beta-cell and neuroprotective actions of fenugreek oil from alloxaninduced diabetes. Immunopharmacollmmunotoxicol. 2010; 32:437445.

125. Moradi kor N, DidarshetabanMB, Saeid Pour HR. Fenugreek (Trigonella foenum-graecum L.) as a valuable medicinal plant. Int J Adv Biol Biom Res.2013; 1:922-931.

126. Ahmadiani A, Javan M, Semnanian S, et al. Anti-inflammatory and antipyretic effects of Trigonella foenum-graecum leaves extract in the rat. J. Ethnopharmacol.2001; 75:283-286.

127. Pundarikakshudu $\mathrm{K}$, Shah DH, Panchal AH, Bhavsar GC Anti-inflammatory activity of fenugreek (Trigonella foenumgraecum Linn) seed petroleum ether extract. Indian J Pharmacol. 2016; 48:441-444.

128. Suresh P, Kavitha ChN, Babu SM, et al. Effect of ethanol extract of Trigonella foenum graecum (Fenugreek) seeds on Freund's adjuvantinduced arthritis in albino rats. Inflammation. 2012; 35:1314-1321.

129. Mandegary A, Pournamdari M, Sharififar F, et al. Alkaloid and flavonoid rich fractions of fenugreek seeds (Trigonella foenum-graecum L.) with antinociceptive and anti-inflammatory effects. Food Chem Toxicol. 2012; 50:2503-2507.

130. Aimbire F, Penna SC, Rodrigues M, Rodrigues KC, Lopes-Martins RA, Sertié JA. Effect of hydroalcoholic extract of Zingiber officinalis rhizomes on LPS-induced rat airway hyperreactivity and lung inflammation. Prostaglandins Leukot Essent Fatty Acids. 2007; 77:129-138

131. Dugasani S, Pichika MR, Nadarajah VD, et al. Comparative antioxidant and anti-inflammatory effects of [6]-gingerol, [8]-gingerol, [10]-gingerol and [6]-shogaol. J Ethnopharmacol. 2010; 127:515-520.

132. Tao $Q F, X u Y$, Lam RY, et al. Diarylheptanoids and a monoterpenoid from the rhizomes of Zingiber officinale: antioxidant and cytoprotective properties. J Nat Prod. 2008; 71:12-17.

133. Mallikarjuna K, Sahitya Chetan P, Sathyavelu Reddy K, et al. Ethanol toxicity: rehabilitation of hepatic antioxidant defense system with dietary ginger. Fitoterapia. 2008; 79:174-178.

134. Ahmed RS, Suke SG, Seth V, et al. Protective effects of dietary ginger (Zingiber officinalesRosc.) on lindane-induced oxidative stress in rats. Phytother Res.2008; 22:902-906.

135. Ajith TA, Aswathy MS, Hema U. Protective effect of Zingiber officinale roscoe against anticancer drug doxorubicin-induced acute nephrotoxicity. Food Chem Toxicol.2008; 46: 3178-3181.

136. Koh EM, Kim HJ, Kim S, et al. Modulation of macrophage functions by compounds isolated from Zingiber officinale. Planta Med. 2009; 75:148-151.

137. Jung $\mathrm{HW}$, Yoon $\mathrm{CH}$, Park $\mathrm{KM}$, et al. Hexane fraction of Zingiberisrhizomecrudus extract inhibits the production of nitric oxide and proinflammatory cytokines in LPS-stimulated BV2 microglial cells via the NF-kappaB pathway. Food Chem Toxicol. 2009; 47:1190-1197.

138. Suresh K, Manoharan S, Vijayaanand MA, et al. Chemopreventive and antioxidant efficacy of (6)-paradol in 7,12-dimethylbenz(a) anthracene induced hamster buccal pouch carcinogenesis. Pharmacological Rep. 2010;62:1178-1185.

139. Lee C, Park GH, Kim CY, Jang JH. [6]-Gingerol attenuates 凶-amyloidinduced oxidative cell death via fortifying cellular antioxidant defense system. Food Chem Toxicol. 2011b;49:1261-1269. 
140. Shanmugam KR, Mallikarjuna K, Kesireddy N, et al. Neuroprotective effect of ginger on anti-oxidant enzymes in streptozotocin-induced diabetic rats. Food Chem Toxicol. 2011; 49:893-897.

141. Stoilova I, Krastanov A, Stoyanova A, et al. Antioxidant activity of a ginger 9extract (Zingiber officinale). Food Chem. 2007; 102: 764770

142. Jagetia G, Baliga M, Venkatesh P. Ginger (Zingiber officinaleRosc.), a dietary supplement, protects mice against radiation-induced lethality: mechanism of action. Cancer BiotherRadiopharm. 2004; 19:422-435.

143. Park KK, Chun KS, Lee JM, et al. Inhibitory effects of [6]-gingerol, a major pungent principle of ginger, on phorbol ester-induced inflammation, epidermal ornithine decarboxylase activity and skin tumor promotion in ICR mice. Cancer Lett. 1998; 129:139-144.

144. Singh G, Kapoor IP, Singh $P$, et al. Chemistry, antioxidant and antimicrobial investigations on essential oil and oleoresins of Zingiber officinale. Food Chem Toxicol.2008; 46:3295-3302.

145. Thomson M, Al-Qattan KK, Al-Sawan SM, et al. The use of ginger (Zingiber officinaleRosc.) as a potential anti-inflammatory and antithrombotic agent. Prostaglandins Leukot Essent Fatty Acids. 2002; 67:475-478.

146. Mishra RK, Kumar A, Kumar A. Pharmacological Activity of Zingiber officinale. Int. J. Pharmaceut. Chemical Sci. 2012; 1:1422-1427.

147. Wilasrusmee $C$, Siddiqui J, Bruch D, et al. In vitro immunomodulatory effects of herbal products. Am Surg.2002; 68:860-864.

148. Zhou HL, Deng YM, Xie QM. The modulatory effects of the volatile oil of ginger on the cellular immune response in vitro and in vivo in mice. J Ethnopharmacol. 2006; 105:301-305.

149. Akinyemi AJ, Adeniyi PA. Effect of Essential Oils from Ginger (Zingiber officinale) and Turmeric (Curcuma longa) Rhizomes on Some Inflammatory Biomarkers in Cadmium Induced Neurotoxicity in Rats. J. Toxicol 2018; 4109491.

150. Puri A, Sahai R, Singh KL, et al. 2000. Immunostimulant activity of dry fruits and plant materials used in indian traditional medical system for mothers after child birth and invalids. J Ethnopharmacol. 71:89-92.

151. Jeena K, Liju VB, Kuttan R. Antioxidant, anti-inflammatory and antinociceptive activities of essential oil from ginger. Ind $\mathrm{J}$ PhysiolPharmacol.2013; 57:51-62.

152. Mahboubi, M. Zingiber officinale Rosc. essential oil, a review on its composition and bioactivity. Clin Phytosci. 2019; 5: 6.

153. Aryaeian N, Shahram F, Mahmoudi M, et al. The effect of ginger supplementation on some immunity and inflammation intermediate genes expression in patients with active Rheumatoid Arthritis. Gene2019; 698:179-185.

154. Kardan M, Rafiei A, Ghaffari J, et al. Effect of ginger extract on expression of GATA3, T-bet and ROR- $₫ t$ in peripheral blood mononuclear cells of patients with Allergic Asthma. Allergollmmunopathol (Madr). 2019; 47:378-385.

155. Lambert JD, Hong J, Kim DH, et al. Piperine enhances the bioavailability of the tea polyphenol (-)-epigallocatechin-3-gallate in mice. J Nutr. 2004; 134:1948-1952.

156. Bae GS, Kim MS, Jung WS, et al. Inhibition of lipopolysaccharideinduced inflammatory responses by piperine. Eur J Pharmacol. 2010; 642:154-162.
157. Sharma A, Gautam S, Jadhav SS. Spice extracts as dose-modifying factors in radiation inactivation of bacteria. J Agric Food Chem.2000; 48:1340-1344.

158. Vijayakumar RS, Nalini N. Efficacy of piperine, an alkaloidal constituent from Piper nigrum on erythrocyte antioxidant status in high fat diet and antithyroid drug induced hyperlipidemic rats. Cell BiochemFunct.2006; 24:491-498.

159. Singh R, Singh N, Saini BS, Rao HS. In vitro antioxidant activity of pet ether extract of black pepper. Indian J Pharmacol. 2008; 40:147151.

160. Kapoor IP, Singh B, Singh G, et al. Chemistry and in vitro antioxidant activity of volatile oil and oleoresins of black pepper (Piper nigrum). $J$ Agric Food Chem. 2009; 57:5358-5364.

161. Liu Y, Yadev VR, Aggarwal BB, Nair MG. Inhibitory effects of black pepper (Piper nigrum) extracts and compounds on human tumor cell proliferation, cyclooxygenase enzymes, lipid peroxidation and nuclear transcription factor-kappa-B. Nat Prod Commun. 2010; 5:1253-1257.

162. Noor Mohamed MS, Jaikumar K, Anand D, et al. Assessment of Cytotoxic and Immunomodulatory Properties of Piper nigrum Linn. (White Pepper) Seed Extract. Int. J. Pharmaceu. Sci. Drug Res. 2017; 9:64-67.

163. Samykutty A, Shetty AV, Dakshinamoorthy G, et al. Piperine, a Bioactive Component of Pepper Spice Exerts Therapeutic Effects on Androgen Dependent and Androgen Independent Prostate Cancer Cells. PLoS One. 2013; 8(6):e65889

164. Sharma S, Kalia NP, Suden P, et al. Protective efficacy of piperine against Mycobacterium tuberculosis. Tuberculosis (Edinb). 2014; 94:389-396.

165. Soutar DA, Doucette CD, Liwski RS, Hoskin DW.Piperine, a Pungent Alkaloid from Black Pepper, Inhibits B Lymphocyte Activation and Effector Functions. Phytother Res. 2017; 31: 466-474.

166. Doucette CD, Rodgers G, Liwski RS, Hoskin DW. Piperine from black pepper inhibits activation-induced proliferation and effector function of T lymphocytes. J Cell Biochem. 2015;116:2577-2588.

167. Majdalawieh AF, Carr RI. In vitro investigation of the potential immunomodulatory and anti-cancer activities of black pepper (Piper nigrum) and cardamom (Elettaria cardamomum). J Med Food.2010; 13:371-381.

168. Pathak N, Khandelwal S. Immunomodulatory role of piperine in cadmium induced thymic atrophy and splenomegaly in mice. Environ ToxicolPharmacol.2009; 28:52-60.

169. Jia HP, Look DC, Shi L.et al. ACE2 receptor expression and severe acute respiratory syndrome coronavirus infection depends on differentiation of human airway epithelia. J Virol. 2005; 79:14614-21.

170. Zahedipour, F, Hosseini, SA, Sathyapalan, T, et al. Potential effects of curcumin in the treatment of COVIDQ19 infection. Phytotherapy Research. 2020; 1- 10. https://doi.org/10.1002/ptr.6738

171. di Mauro Gabriella, Cristina S, Concetta R, et al. SARS-Cov-2 infection: Response of human immune system and possible implications for the rapid test and treatment. Int Immunopharmacol. 2020; 84:106519.

172. Zhou W, Liu Y, Tian D. et al. Potential benefits of precise corticosteroids therapy for severe 2019-nCoV pneumonia. Sig Transduct Target Ther. 2020; 5:18. 


\section{GRAPHICAL ABSTRACT}

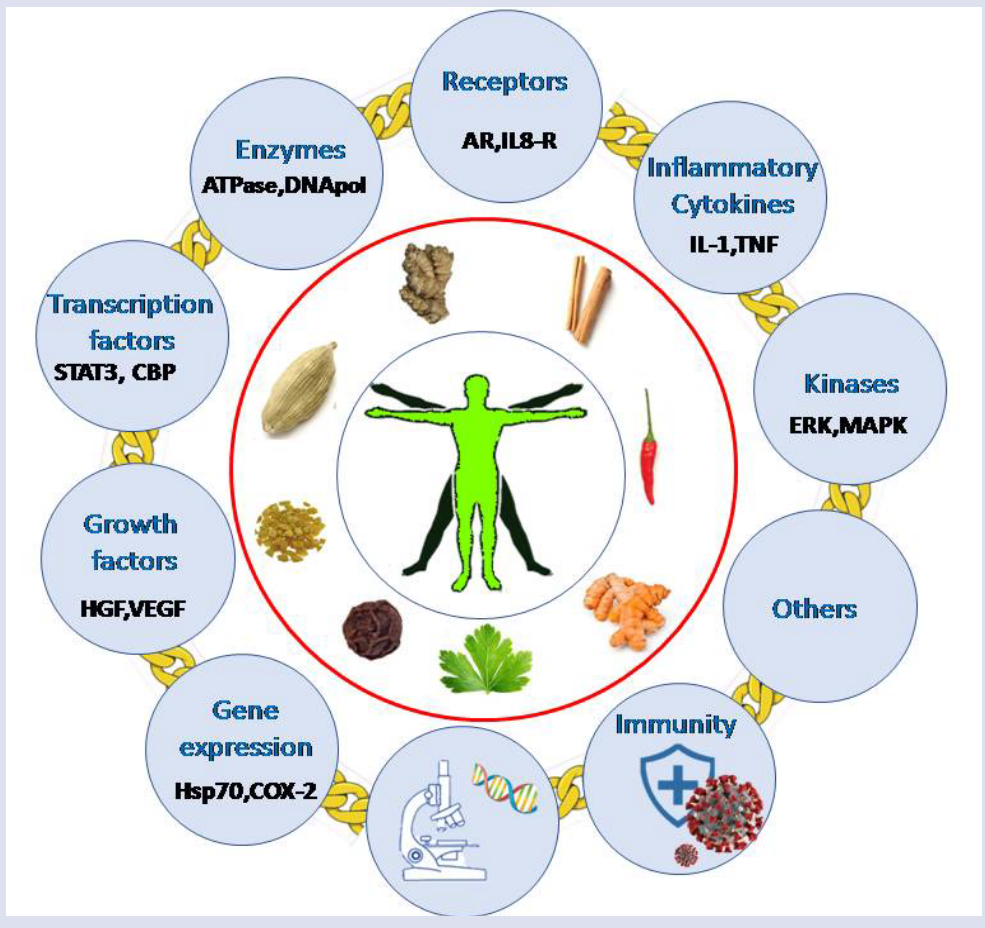

\section{ABOUT AUTHORS}

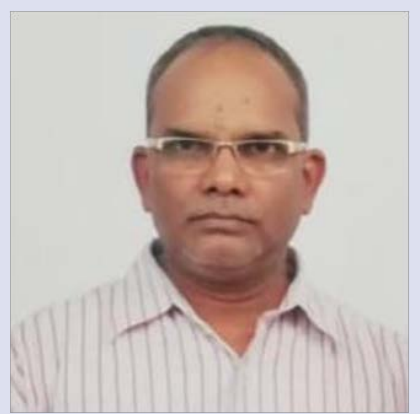

\section{Dr. T. S. Johnson}

DrT S Johnson had his doctoral degree from CSIR-CFTRI, Mysore and EMBO World Program Fellowship at The University of Leiden, The Netherlands. He had 23 years of Corporate R\&D and 3 years of academic experience. He has published 45 papers of international repute, 5 awarded US and European patents. He has co-edited book on Applications of Plant Metabolic Engineering. He is editorial board member of Plant Biotechnology Reports. He has visited countries like Germany, Israel and Australia. He is recipient of Indian Science Congress Association award, Israel Government's MASHAV and AFST's Young Scientist. His interests include phytoextracts, FSSAI, ASU regulatory.

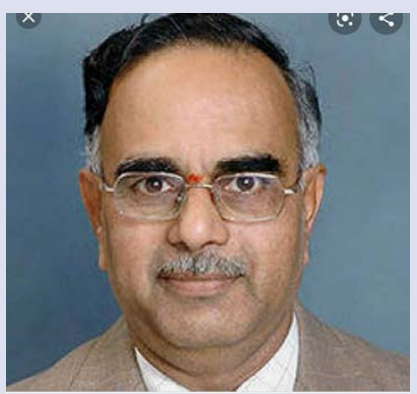

\section{Dr D B Anantha Narayana}

D. B. Anantha Narayana, is a pharmaceutical scientist with over 40 years of experience in Research and Development. He has worked in both Pharmaceutical industry and food industry apart from leading R\&D on botanicals and Ayurvedic products. He has contributed to monograph development for bitanicals. He championed regulations for Notification He has Phytopharmaceuticals as well as Nutraceuticals in India. He currently Chairs committees in Indian Pharmacopoeia Commission and in Food Safety \& Standards Authority. Contributed chapters in national and international book publications, apart from leading thought papers.

Cite this article: Johnson TS, Narayana DBA. Role of Spices in Offering Natural Immunity to Fight Various Diseases. Pharmacog J. $2021 ; 13(2)$ : 600-13. 